\title{
Kalrn plays key roles within and outside of the nervous system
}

\author{
Prashant Mandela', Maya Yankova², Lisa H Conti ${ }^{3}$, Xin-Ming Ma', James Grady ${ }^{4}$, Betty A Eipper ${ }^{1,2}$ and \\ Richard E Mains ${ }^{1 *}$
}

\begin{abstract}
Background: The human KALRN gene, which encodes a complex, multifunctional Rho GDP/GTP exchange factor, has been linked to cardiovascular disease, psychiatric disorders and neurodegeneration. Examination of existing Kalrn knockout mouse models has focused only on neuronal phenotypes. However, Kalirin was first identified through its interaction with an enzyme involved in the synthesis and secretion of multiple bioactive peptides, and studies in C.elegans revealed roles for its orthologue in neurosecretion.
\end{abstract}

Results: We used a broad array of tests to evaluate the effects of ablating a single exon in the spectrin repeat region of Kalrn (KalSR ${ }^{\mathrm{KO} / \mathrm{KO}}$ ); transcripts encoding Kalrn isoforms containing only the second GEF domain can still be produced from the single remaining functional Kalrn promoter. As expected, KalSR ${ }^{\mathrm{KO} / K O}$ mice showed a decrease in anxiety-like behavior and a passive avoidance deficit. No changes were observed in prepulse inhibition of acoustic startle or tests of depression-like behavior. Growth rate, parturition and pituitary secretion of growth hormone and prolactin were deficient in the KalSR ${ }^{\mathrm{KO} / \mathrm{KO}}$ mice. Based on the fact that a subset of Kalrn isoforms is expressed in mouse skeletal muscle and the observation that muscle function in C.elegans requires its Kalrn orthologue, KalSR $\mathrm{KO} / \mathrm{KO}$ mice were evaluated in the rotarod and wire hang tests. KaISR ${ }^{\mathrm{KO} / \mathrm{KO}}$ mice showed a profound decrease in neuromuscular function, with deficits apparent in $\mathrm{KaISR}^{+/ K O}$ mice; these deficits were not as marked when loss of Kalrn expression was restricted to the nervous system. Pre- and postsynaptic deficits in the neuromuscular junction were observed, along with alterations in sarcomere length.

Conclusions: Many of the widespread and diverse deficits observed both within and outside of the nervous system when expression of Kalrn is eliminated may reflect its role in secretory granule function and its expression outside of the nervous system.

Keywords: Neuromuscular junction, Rotarod, Grip strength, Anxiety, Passive avoidance, Rho-GEF

\section{Background}

Mammalian genomes encode 60-70 Rho GDP/GTP exchange factors (Rho-GEFs) and a similar number of Rho GTPase activating proteins (Rho-GAPs) to control the activation and inactivation of $\sim 20$ Rho-family GTPases [1]. The fact that mutations in individual Rho-GEFs are associated with specific disease phenotypes indicates that their functions are not redundant. For example, the KALRN gene, which encodes proteins with two RhoGEF domains, has been associated with stroke [2], early

\footnotetext{
*Correspondence: mains@uchc.edu

'Department of Neuroscience, University of Connecticut Health Science Center, Farmington, CT 06030-3401, USA

Full list of author information is available at the end of the article
}

onset coronary artery disease [2-5], schizophrenia [6-9] and adult attention deficit-hyperactivity disorder [10].

The mouse Kalrn gene includes multiple promoters and several 3 '-untranslated regions which produce functionally distinct isoforms in a tissue-specific and developmentally regulated manner [11-13]. While some Rho-GEFs consist of little more than the catalytic Dbl-homology (DH) domain followed by a pleckstrin homology $(\mathrm{PH})$ domain, Kalirin is a complex protein with multiple catalytic, protein/protein and protein/lipid interaction domains. The longest isoform, Kalirin12, contains a lipid-binding Sec14 domain, nine spectrin-like repeats, two active Rho-GEF domains, two SH3 domains, an Ig/FnIII domain, and a kinase domain [14] (Figure 1). The most abundant isoform in the adult brain, Kalirin7, is almost exclusively 

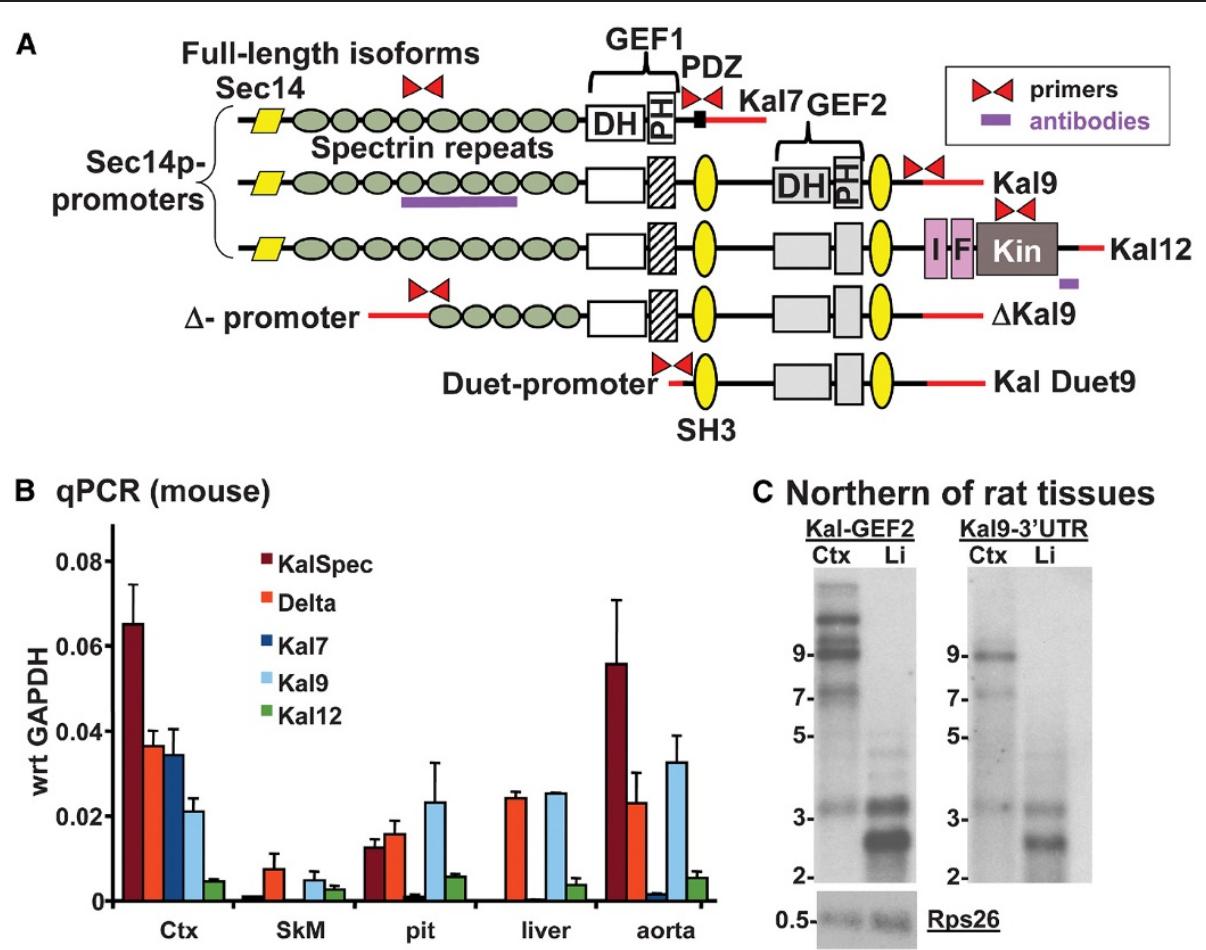

Figure 1 Kalirin isoforms occur in many tissues. A. The major isoforms of Kalirin are diagramed. The qPCR primers used to quantify expression of different regions of the Kalirin gene are indicated and antibody specificities are indicated. DH, Dbl homology; PH, Pleckstrin Homology; GEF1, Guanine nucleotide exchange factor 1; SH3, Src homology domain; GEF2, Guanine nucleotide exchange factor 2; I, Immunoglobulin; F, Fibronectin III; Kin, Kinase domain; red lines, unique 5'- and 3'-untranslated regions. B. Quantitative PCR was used to determine expression of different regions of the Kalirin gene. Data are from individual preparations of RNA and cDNA from 4-8 mice for each tissue. The data were averaged across assays, typically 4 assays per tissue. C. PolyA-containing RNA was prepared from adult rat cortex and liver, and hybridized with $\left[{ }^{32} \mathrm{P}\right]$-labeled probes for the GEF2 domain (1023 nt) or the region immediately $3^{\prime}$ to the Kal9 stop codon (530 nt) [11]. Rps 26 is ribosomal protein S26, used as a loading control.

localized to the postsynaptic density (PSD) $[13,15]$, and plays an essential role in dendritic spine formation and function [16-19]. Kalirin9 and Kalirin12 are more highly expressed during nervous system development [20] and are also expressed in heart, skeletal muscle and endocrine tissue $[20,21]$. The single Kalrn orthologue in C.elegans (UNC-73) and Drosophila (dTrio) plays essential roles both within and outside of the nervous system $[22,23]$.

Multiple promoters and 3'-terminal exons in the Kalrn gene preclude elimination of all isoforms through deletion of any one region of the gene. A knockout mouse for the most prevalent form of Kalirin in the adult brain, Kalirin7, was generated by eliminating its unique $3^{\prime}$-exon $\left(\mathrm{Kal} 7^{\mathrm{KO} / \mathrm{KO}}\right)$ [13]. $\mathrm{Kal}^{\mathrm{KO} / \mathrm{KO}}$ mice have fewer dendritic spines in selected brain regions and exhibit impaired passive avoidance behavior, decreased anxiety-like behavior and accentuated locomotor sensitization to repeated cocaine treatment [13,24]. Cahill et al. [25] replaced Kalrn exons 27 and 28, which encode part of the first GEF domain, with the neomycin resistance gene, generating the KalGEF1 $1^{\mathrm{KO} / \mathrm{KO}}$ mouse [25].
In this study, we flanked exon 13 in the spectrin repeat region with Lox-p sites (KalSR ${ }^{\mathrm{CKO} / \mathrm{CKO}}$ ); excision of this region makes it impossible to regain an inreading-frame protein until exon 28. Global excision yielded $\mathrm{KalSR}^{\mathrm{KO} / \mathrm{KO}}$ mice while breeding of $\mathrm{KalSR} \mathrm{CKO} / \mathrm{CKO}^{\mathrm{C}}$ mice to mice expressing Cre-recombinase under control of the Nestin promoter largely limited excision to the nervous system (KalSR $\left.{ }^{\mathrm{NesKO} / \mathrm{NesKO}}\right)$. Based on our identification of Kalirin through its interaction with a secretory granule enzyme, the association of Kalrn with cardiovascular and psychiatric disease and the roles of $U N C-73$ in C.elegans, we searched for deficits caused by lack of Kalrn within and outside of the nervous system.

\section{Methods}

\section{Creation of global and nervous system specific Kalrn knockout mice}

The basic strategy for ablating exon 13 was the same as for the Kalirin7-specific exon [13]. The $\Delta$ isoforms of Kalirin start at exon 11; exon 13 was chosen because exon 12 would have to be spliced to exon 28 , in the middle of the GEF domain (Figure 2), to remain in the 


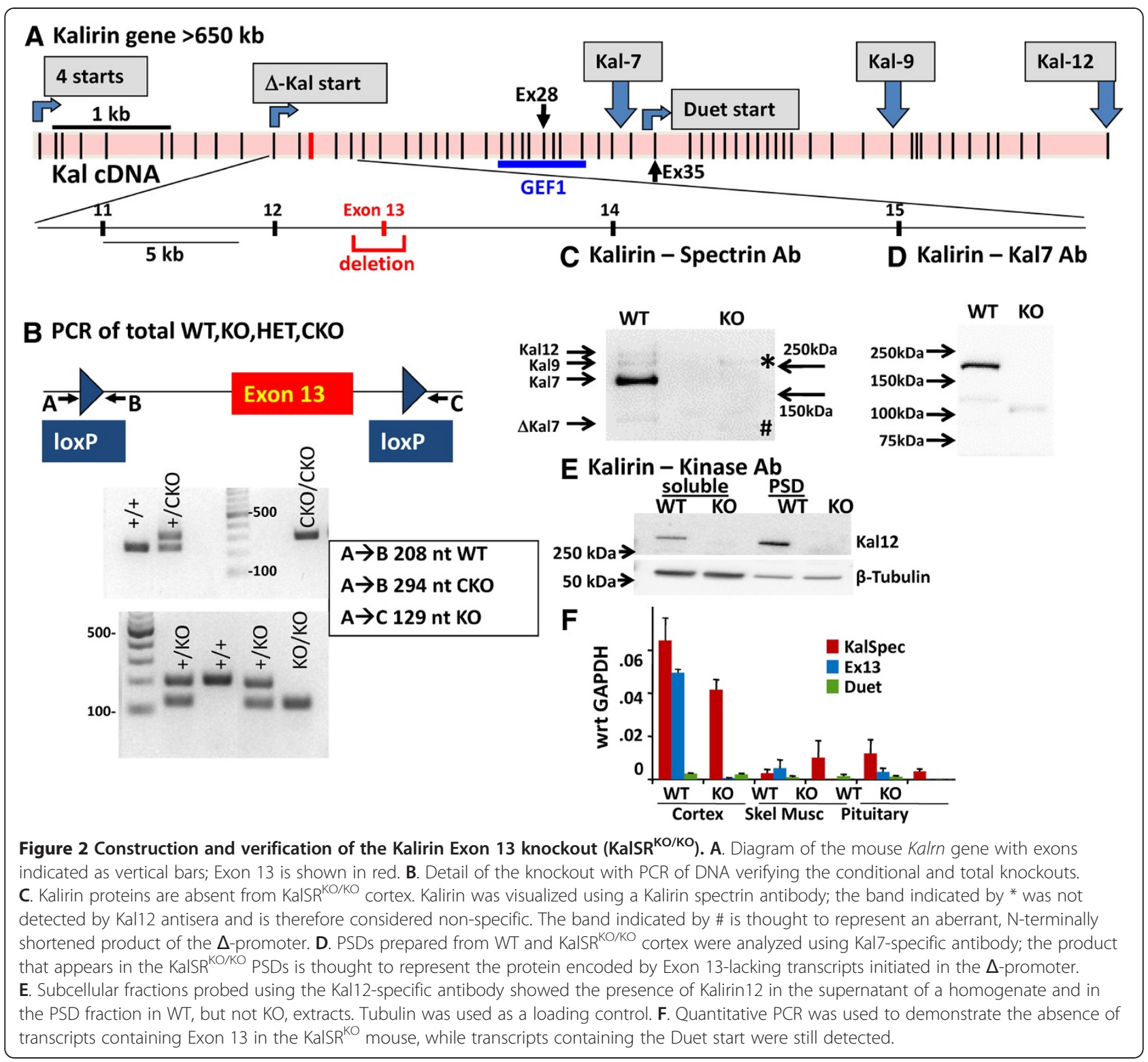

correct reading frame. Lox-p sites were introduced 1.6 $\mathrm{kb}$ upstream (nucleotide 34254054 on chromosome 16, $\mathrm{mm} 9$, July 2007) and $0.6 \mathrm{~kb}$ downstream of exon 13 (a $175 \mathrm{nt}$ exon) (nucleotide 34251804). The strategy for removing the neomycin resistance cassette using flipper mice, breeding the conditional knockout mice into C57Bl/6 (Jackson Laboratories) and eliminating exon 13 using Hprt-Cre females was as described [13]. Mice with Lox-p sites flanking exon 13 are referred to as Kalirin Spectrin Repeat Conditional Knockout (KalSR ${ }^{\mathrm{CKO}}$ ) mice; after Cre-mediated excision of exon 13, mice are referred to as Kalirin Spectrin Repeat Knockout (KalSR ${ }^{\mathrm{KO}}$ ) mice. Both strains have been bred more than 10 generations into the $\mathrm{C} 57 \mathrm{Bl} / 6$ background. KalSR ${ }^{\mathrm{CKO} / \mathrm{CKO}}$ and $\mathrm{KalSR}^{+/ \mathrm{CKO}}$ mice are of normal weight, reproduce well and have an unaltered distribution and level of Kalirin isoforms. $\mathrm{KalSR}^{+/ \mathrm{KO}}$ mice were bred to obtain $\mathrm{KalSR}^{\mathrm{KO} / \mathrm{KO}}$ mice. $\mathrm{KalSR}^{\mathrm{CKO} / \mathrm{CKO}}$ mice were crossed with $\mathrm{C} 57 \mathrm{Bl} / 6$ mice expressing Cre recombinase under the control of the Nestin promoter $[\mathrm{B} 6 . \mathrm{Cg}-\mathrm{Tg}(\mathrm{Nes}-\mathrm{cre}) 1 \mathrm{~K} \mathrm{ln} / \mathrm{J}]$, to yield $\mathrm{KalSR}^{\mathrm{NesKO}}$ mice; expression of Cre recombinase outside of the nervous and endocrine systems is minimal in this mouse, with restricted expression in the vasculature (http://jaxmice.jax.org/strain/003771.html).

\section{Behavioral studies}

Animals were group housed in the Center for Comparative Medicine at the University of Connecticut Health Center (UCHC) with a $12 \mathrm{~h}$ light/dark cycle (lights on 7:00 am - 7:00 pm). All behavioral experiments were 
done in the Scoville Neurobehavioral Suite in accordance with UCHC Institutional Animal Care and Use Committee and National Institutes of Health guidelines. Male and female littermates 2 to 4 months of age were tested during the light phase. All animals were handled daily for at least $4 \mathrm{~d}$ before behavioral testing to minimize experimenter-induced stress. In addition, animals were allowed to habituate to the testing room for 1 $\mathrm{h}$ before testing. Animals were evaluated using several behavioral tests; the less stressful tests preceded those that were more stressful (open field $\rightarrow$ elevated zero maze $\rightarrow$ tail suspension test $\rightarrow$ prepulse inhibition of acoustic startle $\rightarrow$ rotarod $\rightarrow$ grip test $\rightarrow$ object recognition test $\rightarrow$ passive avoidance test $\rightarrow$ restraint stress). Tests were separated by 2 or more days, and the same set of mice was used for all behavioral experiments. Open field, elevated zero maze, passive avoidance, and object recognition (male mice only) tests were performed as described [13]. Briefly, open field behavior was assessed by recording beam breaks for nine fiveminute time bins using a San Diego Instruments clear Plexiglas chamber $(38 \mathrm{~cm} \times 38 \mathrm{~cm})$. Naïve mice were placed onto the elevated zero maze facing into the closed area and the time spent in the open area (all four feet) was monitored for $5 \mathrm{~min}$. Passive avoidance behavior was monitored using a San Diego Instruments 2chamber box; a $0.3 \mathrm{~mA} \times 2 \mathrm{~s}$ scrambled footshock was delivered at the end of the training period, when the mouse was in the dark chamber. Novel object recognition was performed by placing the mouse into a clean rat cage containing two Falcon tubes or two $\mathrm{LEGO}^{\mathrm{R}}$ objects and recording the time spent exploring each object over a three minute trial; the test was repeated the next day using the same object plus a novel object. The elevated zero maze and novel object recognition tests were videotaped and scored by a blinded observer. Data for male and female mice were analyzed separately; when no difference was observed, data were pooled.

\section{Tail suspension}

After taping the tail to a bent coat hanger, mice were suspended $70 \mathrm{~cm}$ above the floor of the cage for $6 \mathrm{~min}$. Mice were videotaped and total time spent immobile (defined as the complete cessation of movement) was scored manually.

\section{Rotarod}

Training sessions (3 days, 3 trials per day) were conducted to acclimate the mice to the rotarod apparatus (Med Associates, VT). Motor coordination was assessed by measuring the length of time each mouse remained on the rotating rod as it accelerated from 4 to $40 \mathrm{rpm}$ over a period of five min. On the 4 th day, mice were tested in the same way three more times and the mean was used as the measure of competence at this task.

\section{Wire hang}

Two parallel steel wires $8 \mathrm{~cm}$ long and separated by $2 \mathrm{~cm}$ were anchored to the middle of a cardboard $(40 \mathrm{~cm} \times 22 \mathrm{~cm}) ;$ a $2 \mathrm{~cm}$ space separated the wires from the cardboard enabling a mouse to grip the wires with all four feet but not to climb onto the wires. The cardboard was suspended $30 \mathrm{~cm}$ above a rat cage containing bedding to prevent injury. Mice were trained for 3 days; on the fourth day, time spent suspended from the wires was measured. On the testing day, each mouse underwent 3 trials and the mean value was used to determine wire hang time.

\section{Acute restraint stress}

When behavioral testing was finished, mice were returned to their home cages for a week. Blood collected via submandibular puncture two days prior to restraint stress was used for measuring basal serum corticosterone levels. Restraint stress was performed between 10:00 AM and noon by placing mice into ventilated 50ml plastic tubes for 15 minutes. Mice were then sacrificed by decapitation; serum prepared from trunk blood was stored at $-80^{\circ} \mathrm{C}$ until assayed for corticosterone (MP Diagnostics) and peptidylglycine $\alpha$-hydroxylating monoxygenase (PHM activity) [26].

\section{Prepulse inhibition of the acoustic startle response}

Male mice were subjected to acoustic startle testing and measurement of prepulse inhibition (PPI) using two identical startle chambers (San Diego Instruments) essentially as described for rats [27]. Mice were placed into a clear acrylic cylindrical chamber enclosed in a soundand vibration-attenuating cabinet equipped with a $5 \mathrm{~W}$ bulb and ventilation fan. The chamber containing the mouse sits on a base that contacts a piezoelectric accelerometer that detects the whole body startle response. Output signals from the accelerometer are collected as 75 sequential $1 \mathrm{msec}$ measurements starting at the onset of the startling stimulus $(120 \mathrm{~dB}, 40 \mathrm{msec})$. Mice were allowed five min of acclimation prior to delivery of the stimuli over a $70 \mathrm{~dB}$ white noise background. The first and last six trials of the session consisted of the startle stimulus alone $(120 \mathrm{~dB}, 40 \mathrm{~ms})$. Trials occurred in a random order and consisted of 12 startle alone trials to calculate \% PPI and 12 prepulse + startle trials at each of 5 prepulse intensities $(3,6,12,15,18 \mathrm{~dB})$, and 8 no stimulus trials. Prepulse stimuli $(20 \mathrm{~ms})$ preceded startle stimuli by $100 \mathrm{~ms}$. Accelerometer signals were rectified and digitized using SR-LAB (San Diego Instruments). Chambers were calibrated daily and matched for sound intensity [27]. 


\section{Cardiovascular measurements}

Blood pressure was measured using a non-invasive CODA tail-cuff blood pressure occlusion system (Kent Scientific). Measurements were taken in a quiet area away from other activity. Conscious animals were introduced into restraining chambers that were placed onto a preheated pad maintained at $30^{\circ} \mathrm{C}$; tail temperature was measured using an infrared sensor and blood pressure measurements were initiated when tail temperature reached $30^{\circ} \mathrm{C}$. Mice were trained for three days and on the fourth day BP recordings were made. Each measurement consisted of 5 acclimatization cycles followed by 15 blood pressure measurement cycles.

\section{Biochemical analyses}

\section{Analysis of DNA and RNA}

DNA prepared from ear or tail snips [13] was used for genotyping with the primers shown in Figure 2B: A, TGTATGCCTTGGAAACAGGC; B, TGTTTTGCCATC GGGAGGAT; C, TGCAAGGAACATCGGGCTTT. The annealing temperature was $51^{\circ} \mathrm{C}$ (for $60 \mathrm{sec}$ ), elongation was at $72^{\circ} \mathrm{C}$ for $30 \mathrm{sec}$, repeated 42 times. Tissue RNA was prepared using Trizol as described [28]. Preparation of cDNA, quantitative polymerase chain reaction (qPCR) primers and conditions were as described for GAPDH, Kal7, Kal9, Kal12, Delta, and Kal-Spectrin [28]. New primers used in this study are shown in Table 1.

\section{Western blot analysis}

Tissue fragments were solubilized in SDS lysis buffer [29] with protease inhibitors added at $10 \mu \mathrm{g} / \mathrm{ml}$ (benzamidine, leupeptin, soybean trypsin inhibitor, and aprotinin). After solubilization at $95^{\circ} \mathrm{C}$, extracts were cleared of insoluble debris by centrifugation at $14,000 \times g$. Solubilized protein was quantified using a bicinchoninic acid assay with bovine serum albumin as the standard (Pierce). SDS-PAGE and immunoblotting with enhanced chemiluminescence were performed as described [13]. Rabbit antiserum JH2582 (raised to recombinant Kalirin spectrin repeats 4 to 7) and affinity-purified rabbit antiserum JH3225 (raised to the C-terminus of Kal12) [11] were visualized using horseradish peroxidase-conjugated anti-rabbit IgG.
Secretion of growth hormone (GH) and prolactin (PRL)

Pools of adult male or female mouse pituitaries were used to prepare cultures as described [30]. Cells were plated at a density of 1.5 pituitaries per well in a protamine coated 96 well plate. Primary cells that had been maintained in culture for 2-3 days were pre-rinsed 2-3 times (15-30 $\mathrm{min}$ each) with secretion medium (complete serum-free medium [CSFM] containing 0.2 $\mathrm{mg} / \mathrm{ml} \mathrm{BSA}$ ). To measure basal secretion cells were fed with secretion medium for $30 \mathrm{~min}$ and the fraction was collected. Following the basal collection, secretagogue stimulated secretion was initiated by adding medium containing $2 \mathrm{mM} \mathrm{BaCl} 2$ and/or $1 \mu \mathrm{M}$ phorbol myristate acetate (PMA) for $30 \mathrm{~min}$. Cells were harvested at the end of the secretion paradigm. Spent media (16\% of sample) and cell lysates (1.6\% of sample) were subjected to SDS-PAGE and western blot analysis using antibodies to GH (JH89) [31] or PRL (IC-5, National Hormone and Peptide Program [NIDDK, National Institutes of Health]); cell content of hormone was normalized to $\gamma$ adaptin (BD Transduction Laboratories).

\section{Visualization of neuromuscular junctions and muscle fine structure \\ Light microscopy}

Nicotinic acetylcholine receptors (AChRs) were visualized in tibialis and diaphragm muscle using $\alpha$-bungarotoxin-tetramethylrhodamine (Sigma-Aldrich, St. Louis, $\mathrm{MO})$ as described [32]. Images were coded and neuromuscular junctions in tibialis muscle were categorized as normal (pretzel-shaped) or open (broken-pretzel). Our categorization was based on the criteria used to distinguish mature neuromuscular junctions from immature (plaque-shaped and partially differentiated) junctions [32]; each neuromuscular junction photographed en face was categorized as "normal" or "open" based on the number of discontinuities observed in its pretzel-like structure; we did not observe immature junctions in the adult tissue examined.

\section{Electron microscopy}

Animals were perfused transcardially with $4 \%$ paraformaldehyde (in $0.1 \mathrm{M}$ sodium phosphate buffer, $\mathrm{pH}$ 7.4) under deep anesthesia with ketamine/xylazine. After fixation, the diaphragm was dissected out and placed into $4 \%$ paraformaldehyde in PBS for one hour. Diaphragm muscle was

Table 1 Primers specific for Exon 13 and Duet

\begin{tabular}{lllll}
\hline Kalirin domain & Oligo name & Sequence & $\mathbf{T}_{\mathbf{m}}\left({ }^{\circ} \mathbf{C}\right)$ & Length $(\mathbf{n t})$ \\
\hline Exon 13 & Ex13-for & CTCAGCGATGTCCAACAACAAGACACC & 61 & 121 \\
\hline Duet & Ex13-rev & GAAGAGCTGTTCACGAGCGGAAGATC & 61 & \\
\hline & Duet-for & CTGAAGTTCCTACCGCCGCGC & 60 & 122 \\
\hline
\end{tabular}


then incubated in PBS containing fluorescently-labeled $\alpha$ bungarotoxin (100nM) at $4^{\circ} \mathrm{C}$ overnight. Neuromuscular junctions (NMJ) were identified under a fluorescence microscope and areas with NMJ's were dissected out as $2 \mathrm{~mm}$ cubes and processed for electron microscopy. The small cubes were further fixed with $2.5 \%$ glutaraldehyde in $0.1 \mathrm{M}$ sodium cacodylate buffer, $\mathrm{pH} 7.2$ at $4^{\circ} \mathrm{C}$. The following day, tissue was rinsed with cacodylate buffer and postfixed in $1 \%$ osmium tetroxide, $0.8 \%$ potassium ferricyanide in $0.1 \mathrm{M}$ cacodylate buffer for $1 \mathrm{~h}$ at room temperature. Following standard procedures for dehydration, the tissues were embedded in Spurr resin. Ultrasections contrasted with uranylacetate were viewed on a Hitachi H-7650 transmission electron microscope and photographed. Coded images of neuromuscular junctions and muscle were scored by a blinded observer. Neuromuscular junctions with well defined boundaries containing neurotransmitter vesicles were considered for analysis. The number of neuromuscular junction folds per length of junction was measured using MetaMorph. The length of the sarcomere, A-band, I-band and Z-band was measured using MetaMorph. Data were obtained from three mice of each genotype.

\section{Statistical analyses}

Data are presented as average \pm SEM. Statistical analyses were performed with GraphPad Prism 4.0 (GraphPad Software, Inc., San Diego, CA, USA) or SPSS software. Data were analyzed using a t-test or one-way ANOVA with Bonferrroni correction as appropriate. Two-way repeated measures ANOVA was used to analyze the interaction between genotype and time in the open field or genotype and prepulse inhibition in the PPI test.

\section{Ethics statement}

Consistent with granting approval, the respective UCHC committees (Institutional Animal Care and Use Committee; Safety) assessed the protocol to ensure the humane use and ethical care of vertebrate animals and the safety of employees. The UCHC Office of Compliance has rigorous policies and a well-established process for vetting actual or potential conflicts of interest. Prior to accepting a grant award, the Office of Research and Sponsored Programs, which serves as the institutional office responsible for submission of applications and administration of awards, coordinates and verifies that all proposed research has been approved by the committee having jurisdiction over the matter.

\section{Results}

\section{Kalirin is expressed within and outside of the} nervous system

Although most studies exploring Kalirin function have focused on its roles in the nervous system, its expression in skeletal muscle, liver and pituitary has been well documented [11,20,30,33]. We used several primer sets to compare Kalrn isoform expression in cortex, skeletal muscle, pituitary, liver and aorta in adult C57BL/6 mice using qPCR (Figure 1B). Cortex exhibited the expected pattern, with high expression of Kalrn isoforms that include all or part of the spectrin repeat region and the exon unique to Kalirin7. Expression of Kalirin7 was barely detectable outside of the nervous system.

Expression of Kalrn isoforms amplified by primers within the unique Kalirin9 3 -untranslated region (Figure 1B) or the GEF2 domain (not shown) was prominent in pituitary, liver and aorta, which also contained high levels of Kalrn transcripts that included all or part of the spectrin repeat region. Adult skeletal muscle expressed Kalrn transcripts amplified by Kalirin9 primers. Transcripts encoding Kalrn isoforms that could include the Sec14p domain (KalSpec primers) were notably absent from skeletal muscle and liver. Northern blot analysis using probes specific for GEF2 and Kalirin9 revealed the presence of 2.5 and $3.3 \mathrm{~kb}$ transcripts that could encode $\Delta$ Kalirin9 and Kal Duet9 (Figure 1A) in liver polyA ${ }^{+}$RNA (Figure $1 \mathrm{C}$ ). The interaction of Kalirin with a secretory granule enzyme and the locomotor role of the C.elegans orthologue of Kalrn led us to include evaluations of pituitary and muscle function in our examination of the $\mathrm{KalSR}^{\mathrm{KO} / \mathrm{KO}}$ mouse.

\section{Generation and validation of $\mathrm{KaISR}^{\mathrm{KO} / \mathrm{KO}}$ mice}

We targeted exon 13 of the Kalrn gene for elimination because splicing of exon 12 to any of the subsequent fifteen exons would yield an out-of-reading frame product. The strategy for eliminating exon 13 is outlined in Figure 2A [13]. As shown in Figure 2B, PCR analysis enabled monitoring of all of the expected genotypes from ear punches gathered when identifying weanlings. All PCR products were verified by DNA sequencing. $\mathrm{KalSR}^{\mathrm{CKO} / \mathrm{CKO}}$ mice were indistinguishable from wildtype C57BL/6 mice. Exon 13 was removed by breeding $\mathrm{KalSR}^{\mathrm{CKO} /+}$ males with Hprt-Cre females; these mice lack $2.25 \mathrm{~kb}$ of chromosome 16 and retain one Lox-p sequence.

$\mathrm{KalSR}^{\mathrm{KO} / \mathrm{KO}}$ mice were generated by mating $\mathrm{KalSR}^{+/ \mathrm{KO}}$ mice and were viable. Western blot analysis using an antibody specific for the spectrin-repeat region of Kalirin confirmed the loss of Kalirin7, 9 and 12 from homogenates of adult cortex (Figure $2 \mathrm{C}$ ). A cross-reactive protein slightly smaller than $\Delta$ Kalirin7 was detected in the $\mathrm{KalSR}^{\mathrm{KO} / \mathrm{KO}}$ sample (Figure $\left.2 \mathrm{C} ; \#\right)$. To determine its identity, transcripts initiated from the $\Delta$-promoter were cloned and sequenced using cortical mRNA from $\mathrm{KalSR}^{+/ \mathrm{KO}}$ mice. Based on this analysis, the band indicated by \# could be encoded by transcripts initiated from the $\Delta$-promoter and lacking exon 13. Stop codons 
follow the first 5 AUG (start) codons in these transcripts but a $107 \mathrm{kDa}$ protein lacking the first 139 residues of $\Delta$ Kalirin7, replaced by 67 residues in a different reading frame, could be produced by translation that started at the sixth AUG. To test this hypothesis, a Kalirin7specific antibody was used to analyze PSDs prepared from wildtype and $\mathrm{KalSR} \mathrm{KO}^{\mathrm{KO} / \mathrm{KO}}$ cortex (Figure 2D); proteins the size of Kalirin7 and $\Delta$ Kalirin7 were absent from the $\mathrm{KalSR}{ }^{\mathrm{KO} / \mathrm{KO}}$ samples and a single product of the predicted mass was apparent. Use of an antibody specific for the region unique to Kalirin12 confirmed its loss from both the soluble and PSD-enriched fractions of adult cortex (Figure 2E).

We used qPCR to verify the elimination of transcripts containing Kalrn exon 13 and to evaluate expression of transcripts initiated at the Kalrn Duet promoter, which is located in the intron preceding exon 35 (Figure 2A). As expected, exon 13-containing transcripts were eliminated in all tissues examined (Figure 2F). Transcripts initiated at the Duet promoter were not eliminated and were present in cortex, skeletal muscle and pituitary. $\mathrm{KalSR}^{\mathrm{KO} / \mathrm{KO}}$ mice lack Kalrn transcripts initiated at five of the six major Kalrn promoters. The consensus for nonsense-mediated decay is that mRNAs are targeted for destruction when translating ribosomes encounter a stop codon followed within a short distance by a downstream splice site [34-36]. For Kalirin transcripts initiated at the full-length Sec14promoters, the first stop codon produced by splicing exon 12 to exon 14 is not followed closely by a splice site; since these transcripts might not be subject to nonsensemediated decay, it was expected that qPCR for the Kalirin Spectrin region (from Exon 10 to Exon 11) could yield normal levels in $\mathrm{KalSR}^{\mathrm{KO} / \mathrm{KO}}$ mice.

\section{KalSR ${ }^{\mathrm{KO} / \mathrm{KO}}$ mice show deficits at parturition}

Once bred more than 10 generations into the $\mathrm{C} 57 \mathrm{Bl} / 6$ background, the yield of pups from $\mathrm{KalSR}^{+/ K O}$ matings matched the expected Mendelian 1:2:1 ratio (Figure 3A). Earlier in the process of breeding from a mixed 129/C57 background, the yield of $\mathrm{KalSR}^{\mathrm{KO} / \mathrm{KO}}$ pups was lower, as

\section{A Breeding}
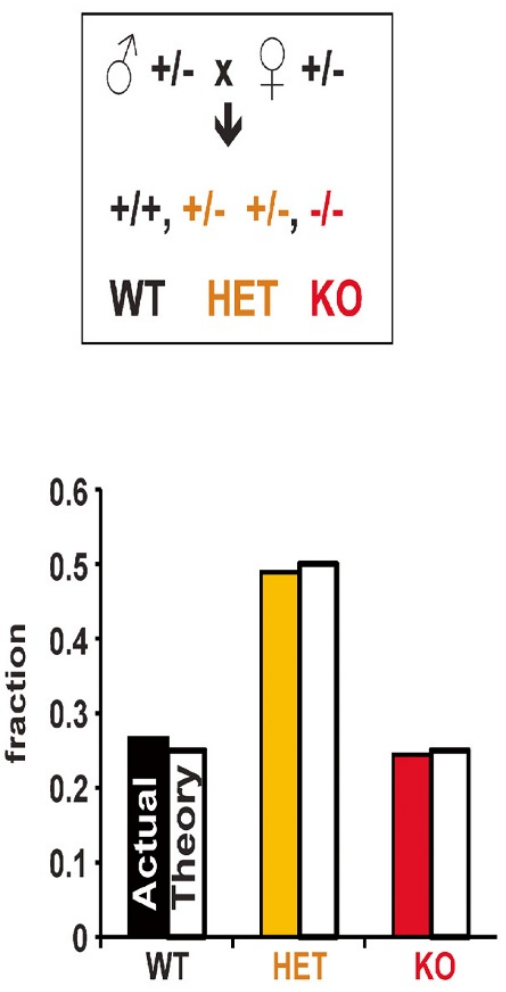
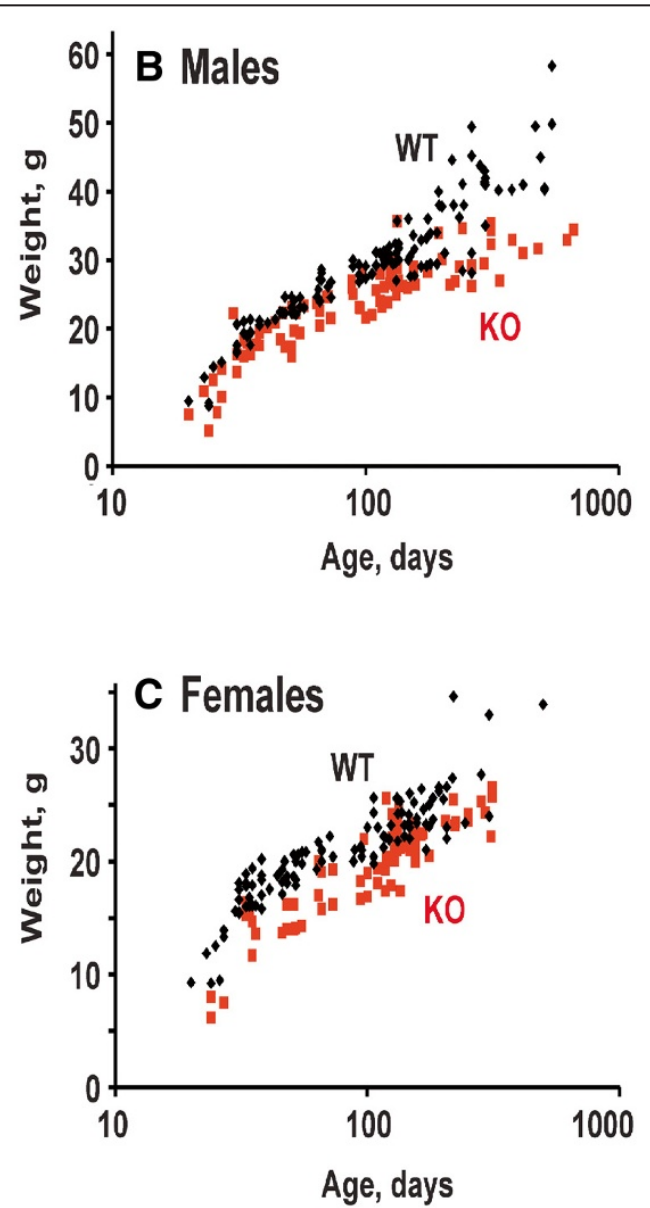

Figure 3 Kalirin Exon 13 knockout results in growth retardation. A. After breeding into a C57BL/6 background, matings of KalSR $\mathrm{KO} /+$ males and females yielded $\mathrm{WT}, \mathrm{KaISR} \mathrm{KO}^{\mathrm{KO}+}$ and $\mathrm{KalSR} \mathrm{KO} / \mathrm{KO}^{\mathrm{K}}$ progeny in a Mendelian ratio. B and $\mathbf{C}$. After weaning, WT and KalSR ${ }^{\mathrm{KO} / \mathrm{KO}}$ mice were weighed at regular intervals. Male (B) KalSR ${ }^{\mathrm{KO} / \mathrm{KO}}$ mice grew more slowly than WT mice. Female (C) KalSR ${ }^{\mathrm{KO} / \mathrm{KO}}$ mice were smaller at weaning but grew at the same rate as WT mice. Neither male nor female KalSR ${ }^{\mathrm{KO} / K O}$ mice grew in a manner identical to $W T$ mice $(p<0.0002)$. 
also seen with the Kalirin $7^{\mathrm{KO} / \mathrm{KO}}$ mice [13]. Although female $\mathrm{KalSR}^{\mathrm{KO} / \mathrm{KO}}$ mice carried litters to term, most could not give birth and died during parturition, in spite of oxytocin administration. KalSR ${ }^{\mathrm{KO} / \mathrm{KO}}$ dams that gave birth showed deficits in nesting, pup rearing and milk letdown.

Weight data for WT and $\mathrm{KalSR}{ }^{\mathrm{KO} / \mathrm{KO}}$ littermates were collected from weaning up to 2 years of age (Figure $3 \mathrm{~B}$, C). A repeated measures general linear mixed model (GLMM) was used to analyze the growth curves using the MIXED procedure in SAS (SAS Institute Inc, Cary, NC) [37]. In these models the unit of analysis is the mouse and each mouse contributes a set of weights over time. A compound symmetry covariance structure was fit. We tested for equality of intercepts (weight at weaning) and slopes (growth rate) for the WT and $\mathrm{KalSR}^{\mathrm{KO} / \mathrm{KO}}$ mice. Male $\mathrm{KalSR}^{\mathrm{KO} / \mathrm{KO}}$ mice were not significantly smaller than WT mice at weaning $(\mathrm{p}=0.15)$ but grew at a slower rate, never attaining the normal growth curve $(\mathrm{p}<0.0002)$ (Figure $3 \mathrm{~B})$. Female $\mathrm{KalSR}^{\mathrm{KO} / \mathrm{KO}}$ mice were smaller than WT mice at weaning $(\mathrm{p}=0.003)$, grew at a similar rate $(\mathrm{p}=0.81)$ but never attained the normal growth curve $(\mathrm{p}<0.0002)$ [37] (Figure 3C).

\section{Cultured pituitary cells reveal cell autonomous deficits in basal secretion in $\mathrm{KaISR}^{\mathrm{KO} / \mathrm{KO}}$}

Kalirin is known to play a pivotal role in secretory granule maturation and storage [30]. Given these previous findings and the deficits in growth (Figure 3) and lactation, we used primary cultures to examine pituitary hormone secretion in $\mathrm{KalSR}{ }^{\mathrm{KO} / \mathrm{KO}}$ mice. Although anterior pituitary somatotropes from $\mathrm{KalSR}^{\mathrm{KO} / \mathrm{KO}}$ mice synthesized and stored growth hormone normally, basal secretion of growth hormone (expressed as the percentage of cell content secreted per hour) was elevated compared to WT (t-test, $\mathrm{p}<0.05)$. In contrast, stimulation of secretion over basal levels by $\mathrm{BaCl}_{2}$ or phorbol myristate acetate was unaltered (Figure 4). Normal growth depends on pulsatile release of growth hormone [38], which reflects both hypothalamic input and nutrient feedback; any disruption in the normal pattern could contribute to deficient growth.

Prolactin secretion showed a similar genotypic difference, with increased basal secretion by $\mathrm{KalSR}^{\mathrm{KO} / \mathrm{KO}}$ lactotropes; since lactotropes in vivo are subject to tonic inhibition by dopamine, basal secretion of PRL in cell culture is substantially higher than basal secretion of GH. KalSR ${ }^{\mathrm{KO} / \mathrm{KO}}$ and wildtype lactotropes did not differ in their ability to increase prolactin secretion over basal levels in response to $\mathrm{BaCl}_{2}$ or PMA (Figure 4).

Similarities in blood pressure, ability to respond to stress and basal locomotor activity in WT and KaISR ${ }^{\mathrm{KO} / \mathrm{KO}}$ mice

Since Kalirin has been implicated in early onset cardiovascular disease [39], resting blood pressure was evaluated in

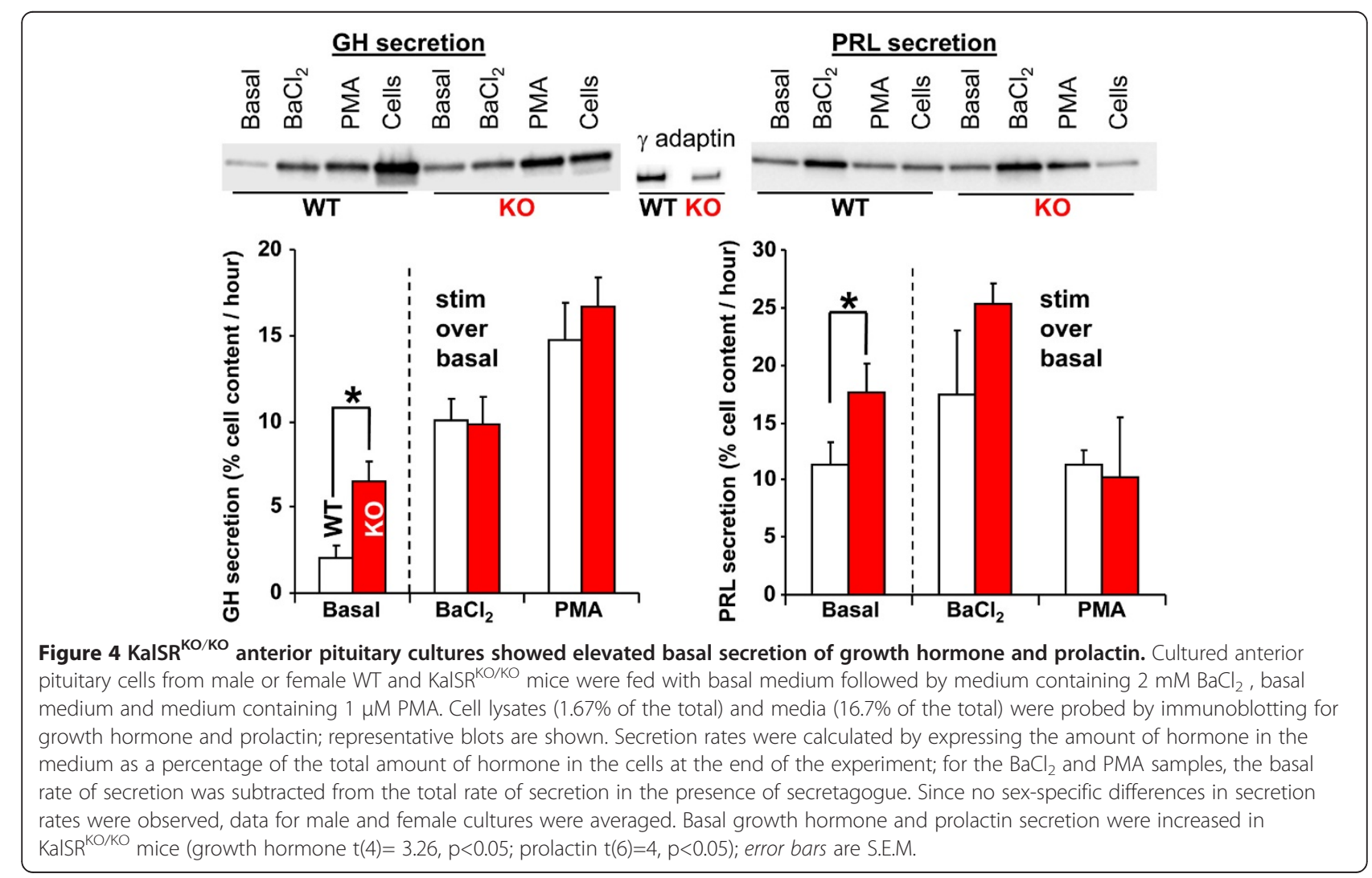


$\mathrm{WT}$ and $\mathrm{KalSR}{ }^{\mathrm{KO} / \mathrm{KO}}$ mice; no significant differences were observed in this parameter, but Fanaroff et al. [5] have reported a role for Kalrn in smooth muscle cell migration/proliferation and atherogenesis (Figure 5A).

Our earlier work on the role of Kalrn in pituitary cells, deficits in peptidergic secretion in C. elegans expressing UNC-73 mutants and deficits in basal growth hormone and prolactin secretion by pituitary cells lacking Kalrn suggested that there might be widespread alterations in peptidergic secretion in $\mathrm{KalSR}^{\mathrm{KO} / \mathrm{KO}}$ mice. To evaluate this possibility, serum levels of a widely expressed secretory granule enzyme were monitored (Figure 5B); serum PHM activity was identical in WT and $\mathrm{KalSR}^{\mathrm{KO} / \mathrm{KO}}$ mice. As another test of peptidergic function, restraint stress was used to stimulate the hypothalamic-pituitaryadrenal axis in $\mathrm{KalSR}{ }^{\mathrm{KO} / \mathrm{KO}}$ mice (Figure $5 \mathrm{C}$ ); secretion of both hypothalamic corticotropin releasing hormone and pituitary adrenocorticotropic hormone is required for a normal response. Neither basal levels of corticosterone nor the ability to secrete corticosterone in response to stress was altered in male or female $\mathrm{KalSR}^{\mathrm{KO} / \mathrm{KO}}$ mice; as expected, corticosterone levels rose higher in female than in male mice after restraint stress (Figure 5C) [40].

Since many of the behavioral tests to be conducted rely on locomotor activity, we evaluated spontaneous locomotor activity in an open field chamber for $45 \mathrm{~min}$; there were no significant differences between WT and $\mathrm{KalSR}^{\mathrm{KO} / \mathrm{KO}}$ mice (Figure 5D).

\section{Behavioral analysis of KalSR ${ }^{\mathrm{KO} / \mathrm{KO}}$ mice}

KALRN has been genetically associated with several neuropsychiatric disorders; therefore a battery of behavioral tests was carried out on WT and $\mathrm{KalSR}^{\mathrm{KO} / \mathrm{KO}}$ mice. Since Kalirin7 is also absent in $\mathrm{KalSR}^{\mathrm{KO} / \mathrm{KO}}$ mice, we first
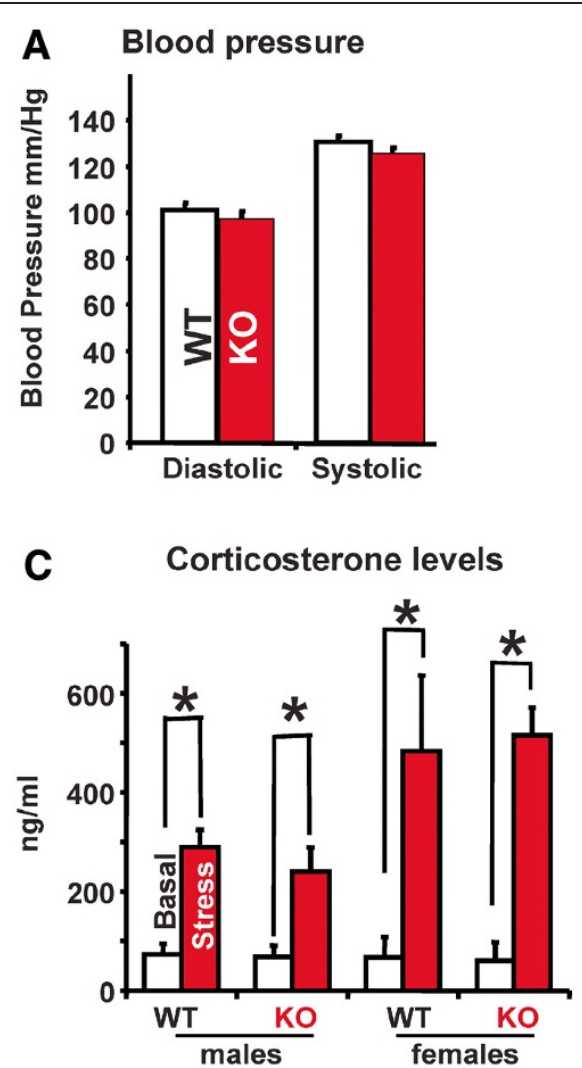

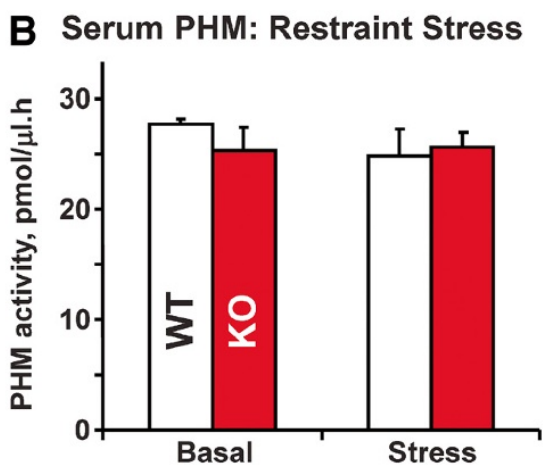

D Open field ambulation

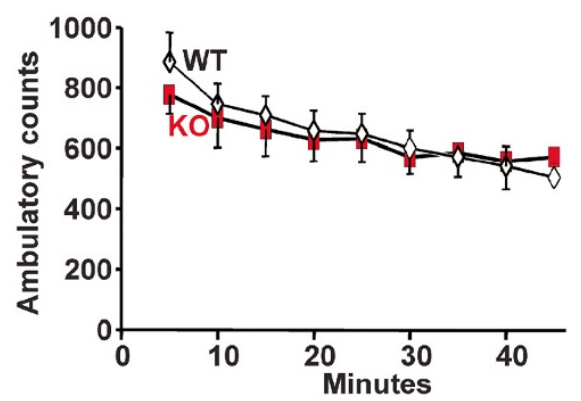

Figure 5 Physiological and behavioral similarities between $\mathrm{KaISR}^{\mathrm{KO} / \mathrm{KO}}$ and WT mice. A. Blood pressure was measured in conscious animals using the tail-cuff method (CODA-2, Kent Scientific, Torrington, CT). Mice were trained for three days and on the fourth day BP recordings were made. Each measurement consisted of 5 acclimatization cycles followed by 15 BP measurements cycles; data for male and female mice did not differ and were pooled. There were no significant differences in the BP of WT and KalSR ${ }^{\mathrm{KO} / \mathrm{KO}}$ mice; error bars are S.E.M. B. Sera from male and female mice collected under basal conditions or after restraint stress (15 min) were subjected to PHM assay. Data for males and females did not differ and no significant differences were found between WT and KalSR ${ }^{\mathrm{KO} / \mathrm{KO}}$ mice; error bars are S.E.M. C. Serum corticosterone levels were measured in male and female mice under basal conditions and after a 15 min restraint stress; data for male and female mice are shown separately. No significant differences were found between genotypes; error bars are S.E.M. D. In the open field, WT and KalSR KO/KO mice (males and females behaved similarly) showed time dependent decreases in spontaneous locomotor activity $(F(8,208)=32.91 \mathrm{p}<0.001)$, with no significant difference between genotypes over the 45 min test. 
used the tests that revealed deficits in the $\mathrm{Kal} 7^{\mathrm{KO} / \mathrm{KO}}$ mice. $\mathrm{WT}, \mathrm{KalSR}^{\mathrm{KO} /+}$ and $\mathrm{KalSR}^{\mathrm{KO} / \mathrm{KO}}$ mice were evaluated in the elevated zero maze; there was a clear effect of genotype on time spent in the open area, indicating a decrease in anxiety-like behavior (Figure $6 \mathrm{~A}$ ). $\mathrm{KalSR}^{\mathrm{KO} / \mathrm{KO}}$ mice spent a significantly longer time in the open area of the elevated zero maze than WT mice (Figure 6A). $\mathrm{KalSR}^{+/ \mathrm{KO}}$ mice did not differ significantly from $\mathrm{WT}$ or $\mathrm{KalSR}^{\mathrm{KO} / \mathrm{KO}}$ mice (Figure 6A).

Since KALRN transcript and Kalirin protein levels were reduced in hippocampi collected from Alzheimers patients [41], we wanted to test $\mathrm{KalSR}^{\mathrm{KO} / \mathrm{KO}}$ mice in hippocampal dependent tasks. Passive avoidance conditioning tests hippocampus-dependent memory [13]. During the training session, WT, $\mathrm{KalSR}^{+/ \mathrm{KO}}$ and $\mathrm{KalSR}^{\mathrm{KO} / \mathrm{KO}}$ mice showed the same latency to cross to the dark side of the chamber (Figure 6B). When tested $24 \mathrm{~h}$ after receiving a single foot shock, it was clear that genotype had a significant effect on the response. KalSR ${ }^{\mathrm{KO} / \mathrm{KO}}$ mice exhibited a significantly decreased latency to cross to the foot shock-paired side relative to WT mice. Once again, the $\mathrm{KalSR}^{+/ \mathrm{KO}}$ mice exhibited a response intermediate to that of WT and $\mathrm{KalSR}^{\mathrm{KO} / \mathrm{KO}}$ mice.

$\mathrm{Kal} 7^{\mathrm{KO} / \mathrm{KO}}$ mice performed normally in the radial arm maze and in tests of novel object recognition [13]. $\mathrm{KalSR}^{\mathrm{KO} / \mathrm{KO}}$ mice spent significantly more time exploring both objects on the pretest day than did WT mice (Figure 6C). The total time spent exploring objects was also significantly higher for $\mathrm{KalSR}^{\mathrm{KO} / \mathrm{KO}}$ mice on the test day, but $\mathrm{KalSR}^{\mathrm{KO} / \mathrm{KO}}$ mice recognized the novel object as well as WT mice (Figure 6C). The increased object exploration observed in $\mathrm{KalSR}^{\mathrm{KO} / \mathrm{KO}}$ mice may reflect their decreased anxiety-like behavior or may reflect impaired response habituation [42] (Figure 6A).

Additional tests were used to evaluate the behavior of the $\mathrm{KalSR}^{\mathrm{KO} / \mathrm{KO}}$ mice. Depression-like behavior was

\section{A}

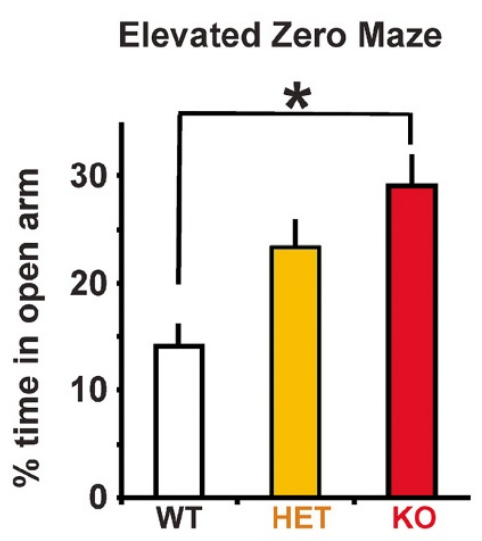

C

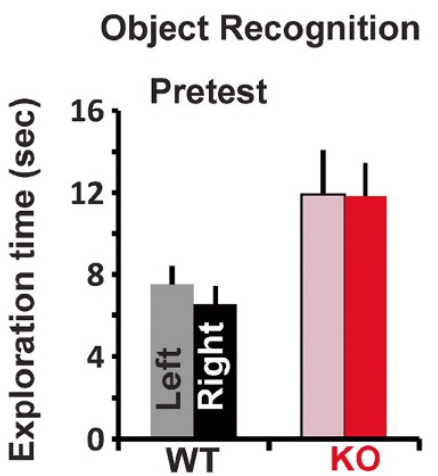

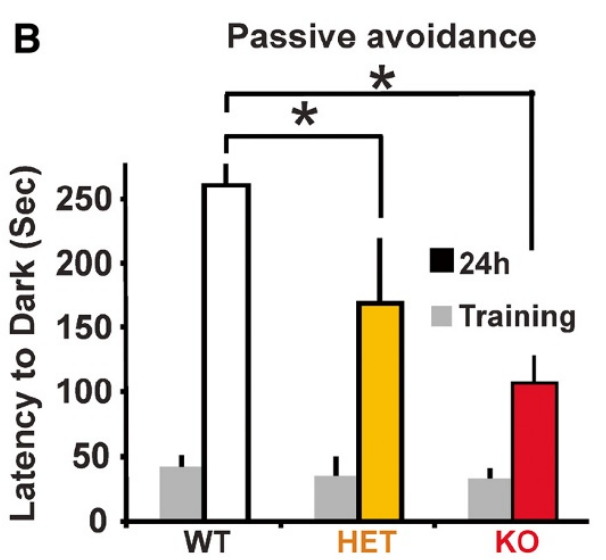

Novel Object

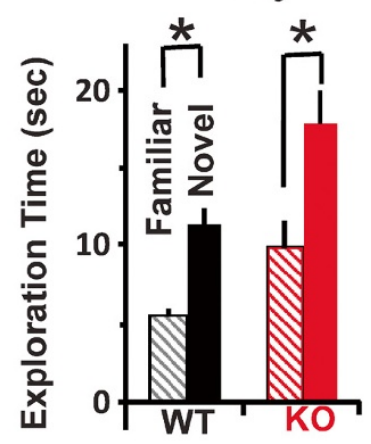

Figure $6 \mathrm{KalSR}^{\mathrm{KO} / \mathrm{KO}}$ mice exhibit several behavioral changes similar to Kal7 ${ }^{\mathrm{KO} / \mathrm{KO}}$ mice. A. Naive mice were subjected to the elevated zero maze test for 5 min. KalSR ${ }^{\mathrm{KO} / \mathrm{KO}}$ mice spent more time in the open arm than WT mice $(F(2,35)=9.926, p<0.001)$; error bars are S.E.M. B. Genotype dependent impairment was evident in the passive avoidance test, with the greatest effect on $\mathrm{KaISR}^{\mathrm{KO} / \mathrm{KO}}$ mice $(F(2,42)=9.658 ; p<0.001)$. Bonferroni corrected t-tests revealed a difference between WT and $\mathrm{KalSR}^{\mathrm{KO} /+}(\mathrm{p}<0.05)$ mice but not between $\mathrm{KalSR}^{+/ \mathrm{KO}}$ and $\mathrm{KalSR} \mathrm{KO} / \mathrm{KO}^{\text {mice. }}$ C. A novel object recognition paradigm was used to determine learning and memory impairments in the KalSR ${ }^{\mathrm{KO} / \mathrm{KO}}$ mice. Both WT and $\mathrm{KalSR} \mathrm{KO}^{\mathrm{KO}}$ mice spent significantly more time with the novel object $(\mathrm{WT}, \mathrm{t}(28)=8, \mathrm{p}<0.001)(\mathrm{KO}, \mathrm{t}(28)=5.5, \mathrm{p}<0.001)$, but $\mathrm{KalSR} \mathrm{KO} / \mathrm{KO}^{\text {mice }}$ showed increased exploratory behavior compared to WT mice $(t(28)=4.519, p<0.05)$; error bars are S.E.M. Male and female mice responded similarly in elevated zero maze and passive avoidance tests and data were pooled; the novel object recognition test was carried out only on male mice. 
evaluated using the tail suspension test (Figure 7A). There was no difference in immobility time for WT and $\mathrm{KalSR}^{\mathrm{KO} / \mathrm{KO}}$ mice.

Prepulse inhibition is the decrease in startle response to an intense auditory stimulus that is preceded by a smaller auditory prepulse [43]. Decreased KALRN mRNA levels were reported in the prefrontal cortex of subjects with schizophrenia [7,44], and PPI deficits due to altered sensory motor gating have been reported in schizophrenic patients and psychosis-prone individuals [45]. The startle response to pulse-alone trials in $\mathrm{KalSR}^{\mathrm{KO} / \mathrm{KO}}$ mice was significantly lower than in WT mice (Figure 7B). Contrary to our expectations, there was no significant difference between $\mathrm{WT}$ and $\mathrm{KalSR}^{\mathrm{KO} / \mathrm{KO}}$ mice in the prepulse induced inhibition of acoustic startle. However, the diminished startle response observed in the $\mathrm{KalSR}^{\mathrm{KO} / \mathrm{KO}}$ suggested a role for altered neuromuscular function, which was examined directly.

\section{$\mathrm{KaISR}^{\mathrm{KO} / \mathrm{KO}}$ and $\mathrm{KaISR}^{+/ \mathrm{KO}}$ mice show deficits in neuromuscular function}

Motor coordination was first tested using a rotarod; mice trained for three days were tested on the fourth day. Both the $\mathrm{KalSR}^{+/ \mathrm{KO}}$ and $\mathrm{KalSR}^{\mathrm{KO} / \mathrm{KO}}$ mice showed a decreased ability to perform this task relative to WT mice (Figure $8 \mathrm{~A}$ ); KalSR ${ }^{\mathrm{KO} / \mathrm{KO}}$ mice were more affected than $\mathrm{KalSR}^{\mathrm{KO} /+}$ mice. Skeletal muscle function was further probed using a wire hang test. $\mathrm{KalSR}^{+/ \mathrm{KO}}$ and $\mathrm{KalSR}^{\mathrm{KO} / \mathrm{KO}}$ mice showed a drastic reduction in their ability to suspend themselves from a wire compared to WT mice (Figure 8B).

Since Kalrn is expressed in both motor neurons and skeletal muscle, the phenotype observed could result from the loss of Kalrn expression in either or both cell types. In order to direct elimination of Kalrn expression to the nervous system, KalSR ${ }^{\mathrm{CKO} / \mathrm{CKO}}$ mice were mated with nestin-Cre mice [46]. In these mice Cre is broadly expressed throughout the central nervous system from early embryonic development through adulthood; restricted expression is also observed in the vasculature and scattered cells in a wide variety of tissues (http:// jaxmice.jax.org/strain/003771.html). KalSR ${ }^{\text {NesKO/NesKO }}$ and control KalSR ${ }^{\mathrm{CKO} / \mathrm{CKO}}$ mice were evaluated in the rotarod and wire hang tests. Since $\mathrm{Kal} 7^{\mathrm{KO} / \mathrm{KO}}$ mice would be expected to mimic neuron-specific elimination of Kalrn expression, they were evaluated using the same tests. Compared to $\mathrm{KalSR}^{\mathrm{KO} / \mathrm{KO}}$ mice, KalSR ${ }^{\mathrm{NesKO} / \mathrm{NesKO}}$ mice exhibited less of a decrease in their ability to remain on the rotarod (Figure $8 \mathrm{C}$ ); the performance of $\mathrm{Kal} 7^{\mathrm{KO} / \mathrm{KO}}$ mice did not differ from that of WT mice in this test. In the wire hang test, $\mathrm{KalSR}^{\mathrm{NesKO} / \mathrm{NesKO}}$ mice were indistinguishable from the KalSR ${ }^{\mathrm{CKO} / \mathrm{CKO}}$ controls and did not exhibit the profoundly impaired performance observed in $\mathrm{KalSR}^{\mathrm{KO} / \mathrm{KO}}$ mice (Figure $8 \mathrm{D}$ ); $\mathrm{Kal} 7^{\mathrm{KO} / \mathrm{KO}}$ mice remained suspended from the wire for a longer time than WT mice.

\section{$\mathrm{KaISR}^{\mathrm{KO} / \mathrm{KO}}$ mice show deficits in neuromuscular junction} and muscle structure

In order to evaluate the structure of the neuromuscular junction, tibialis muscles from $\mathrm{KalSR}^{\mathrm{KO} / \mathrm{KO}}$ and WT mice were visualized after binding fluorescently tagged bungarotoxin to the nicotinic aceylcholine receptor (Figure 9A). The expected compact, pretzel-like structures were consistently observed in WT muscle while a more open, less well organized pattern was common in
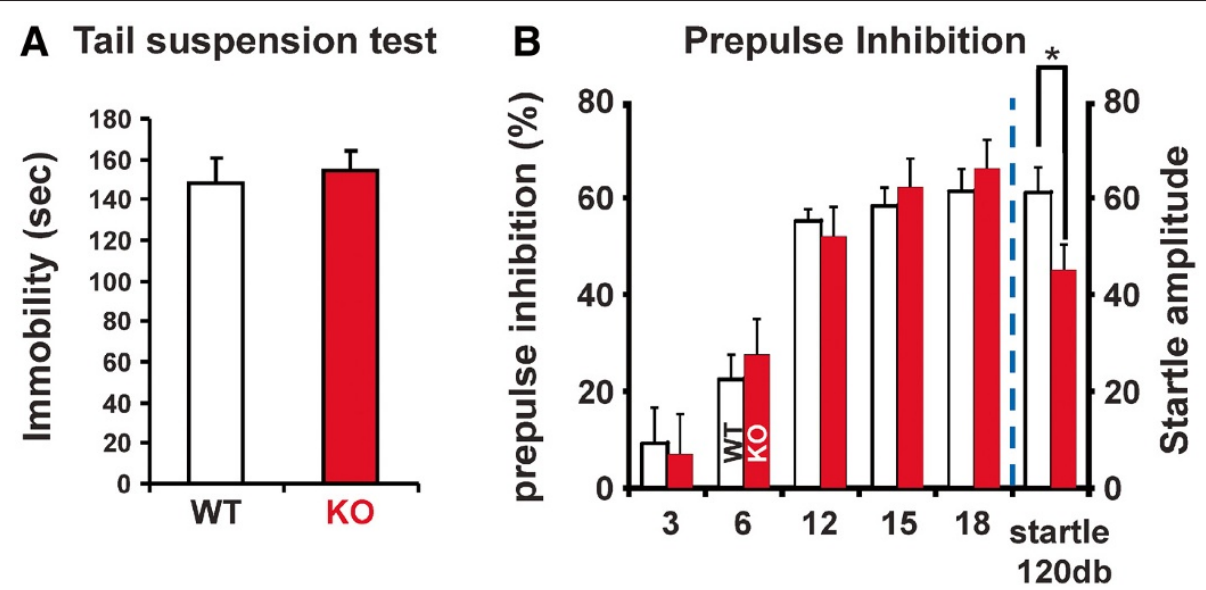

Figure $7 \mathrm{KalSR}^{\mathrm{KO} / \mathrm{KO}}$ mice lack depressive-like symptoms and have normal sensorimotor gating. A. WT and $\mathrm{KalSR} \mathrm{KO}^{\mathrm{KOO}}$ mice (male and female) showed no significant difference when subjected to tail suspension, to determine depressive-like behavior $(t(16)=0.36 ; p>0.05)$. B. Behavioral similarities exist between $\mathrm{WT}$ and $\mathrm{KaISR} \mathrm{KO}^{\mathrm{KO}}$ mice in the prepulse inhibition test; male mice of both genotypes showed a similar and significant prepulse inhibition (left $y$-axis) at all intensities $(F(4,56)=61.27 p<0.001)$. In the pulse alone trials, KalSR ${ }^{\mathrm{KO} / \mathrm{KO}}$ mice showed a decreased startle response (right $y$-axis) compared to WT mice (t $(14)=2.26 ; p<0.05$ ); error bars are S.E.M. 


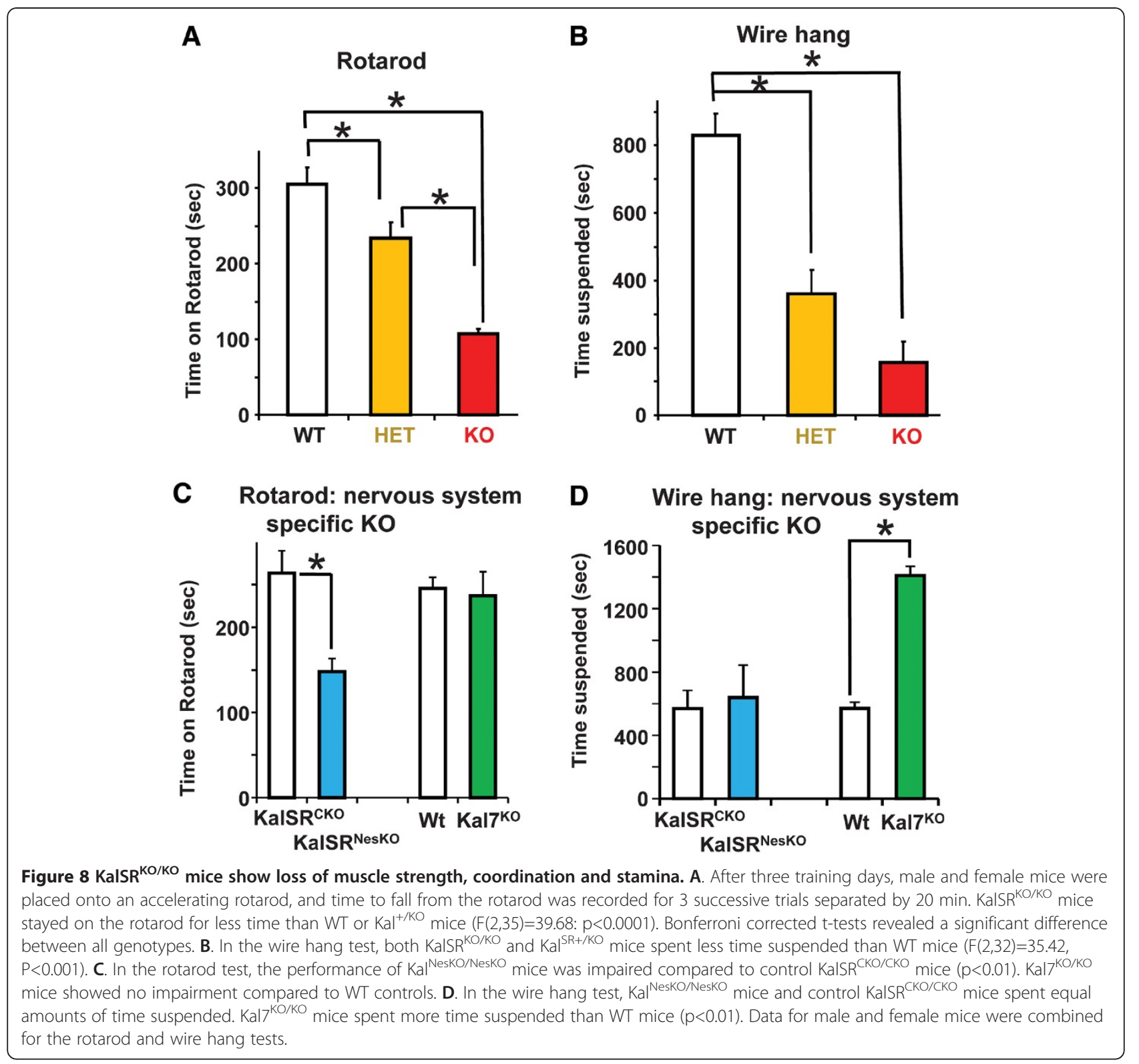

the $\mathrm{KalSR}^{\mathrm{KO} / \mathrm{KO}}$ muscle. Categorization using established criteria [32] suggested a significant difference in the organization of the nicotinic acetylcholine receptors at the neuromuscular junction in $\mathrm{KalSR}^{\mathrm{KO} / \mathrm{KO}}$ mice (Figure 9B).

For a more detailed, quantitative analysis, we turned to the diaphragm muscle; neuromuscular junctions were localized in fixed tissue and analyzed by transmission electron microscopy. In both WT and $\mathrm{KalSR}^{\mathrm{KO} / \mathrm{KO}}$ mice, muscle fibers were well organized (Figure 10A,B), with peripheral nuclei and normal mitochondrial content. Sarcomere length was increased in $\mathrm{KaISR}^{\mathrm{KO} / \mathrm{KO}}$ mice, reflecting an increase in I-band length; A-band length was unaltered (Figure 10E). Z-line thickness was decreased in $\mathrm{KalSR}^{\mathrm{KO} / \mathrm{KO}}$ muscle.
Neuromuscular junctions were identified based on the apposition of specialized regions of muscle membrane and nerve endings filled with synaptic vesicles and mitochondria [47]. Well organized junctional folds closely apposed to nerve terminals filled with synaptic vesicles were readily found in WT tissue (Figure 10C). In contrast, both the nerve terminals and junctional folds were disturbed in $\mathrm{KalSR}^{\mathrm{KO} / \mathrm{KO}}$ mice (Figure 10D). The number of junctional folds/ $\mu \mathrm{m}$ of synaptic membrane was quantified by a blinded observer and was decreased in the $\mathrm{KalSR}^{\mathrm{KO} / \mathrm{KO}}$ mice (Figure 10F). In addition, mitochondria often accumulated in the presynaptic endings of $\mathrm{KalSR}{ }^{\mathrm{KO} / \mathrm{KO}}$ mice. Differences in both neuronal and muscle tissue may contribute to the altered rotarod and wire hang performance. 


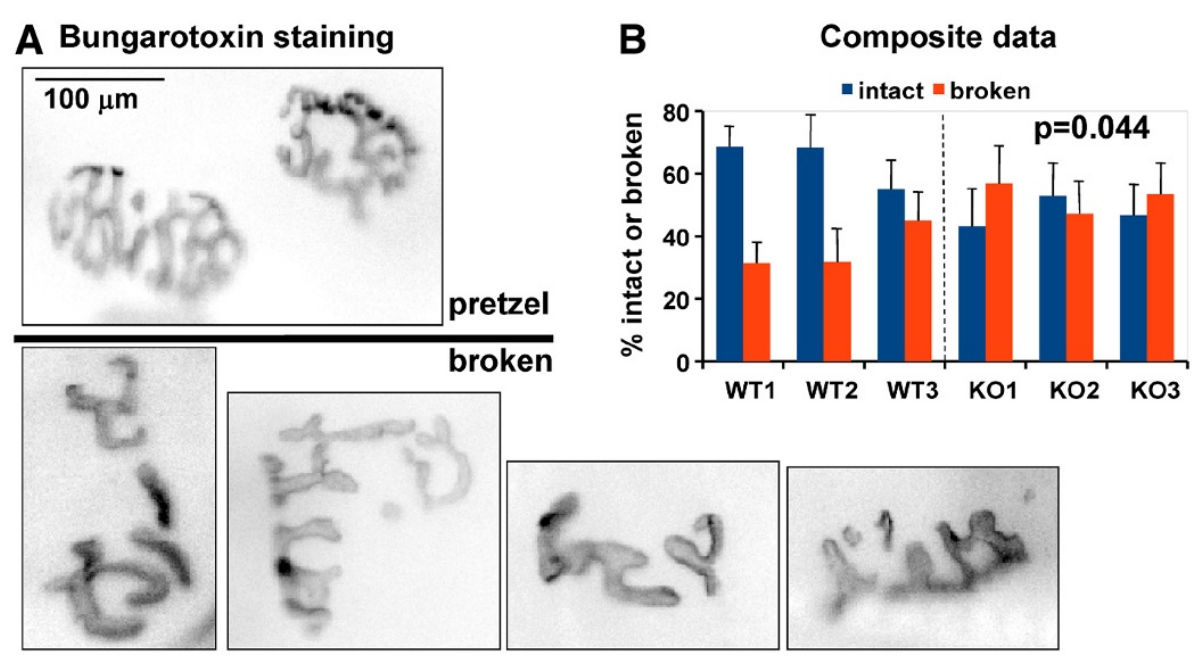

Figure 9 Neuromuscular junctions are abnormal in KaISR ${ }^{\mathrm{KO} / \mathrm{KO}}$ mice. A. Individually teased fixed anterior tibialis muscles of adult WT and $\mathrm{KaISR} \mathrm{KO} / \mathrm{KO}$ male and female mice were incubated with fluorescently tagged a-BTX to visualize postsynaptic AChR clusters. B. Neuromuscular junctions were categorized as normal (pretzel-shaped) or open (broken) and the percentage of the junctions categorized as normal was calculated for three WT and three KalSR ${ }^{\mathrm{KO} / \mathrm{KO}}$ mice; bars show data from a single mouse. KalSR ${ }^{\mathrm{KO} / \mathrm{KO}}$ mice have a lower fraction of intact pretzel shaped junctions (t-test; $\mathrm{p}=0.044$ ) and a larger fraction of broken junction shapes (t-test; $\mathrm{p}=0.044$ ).

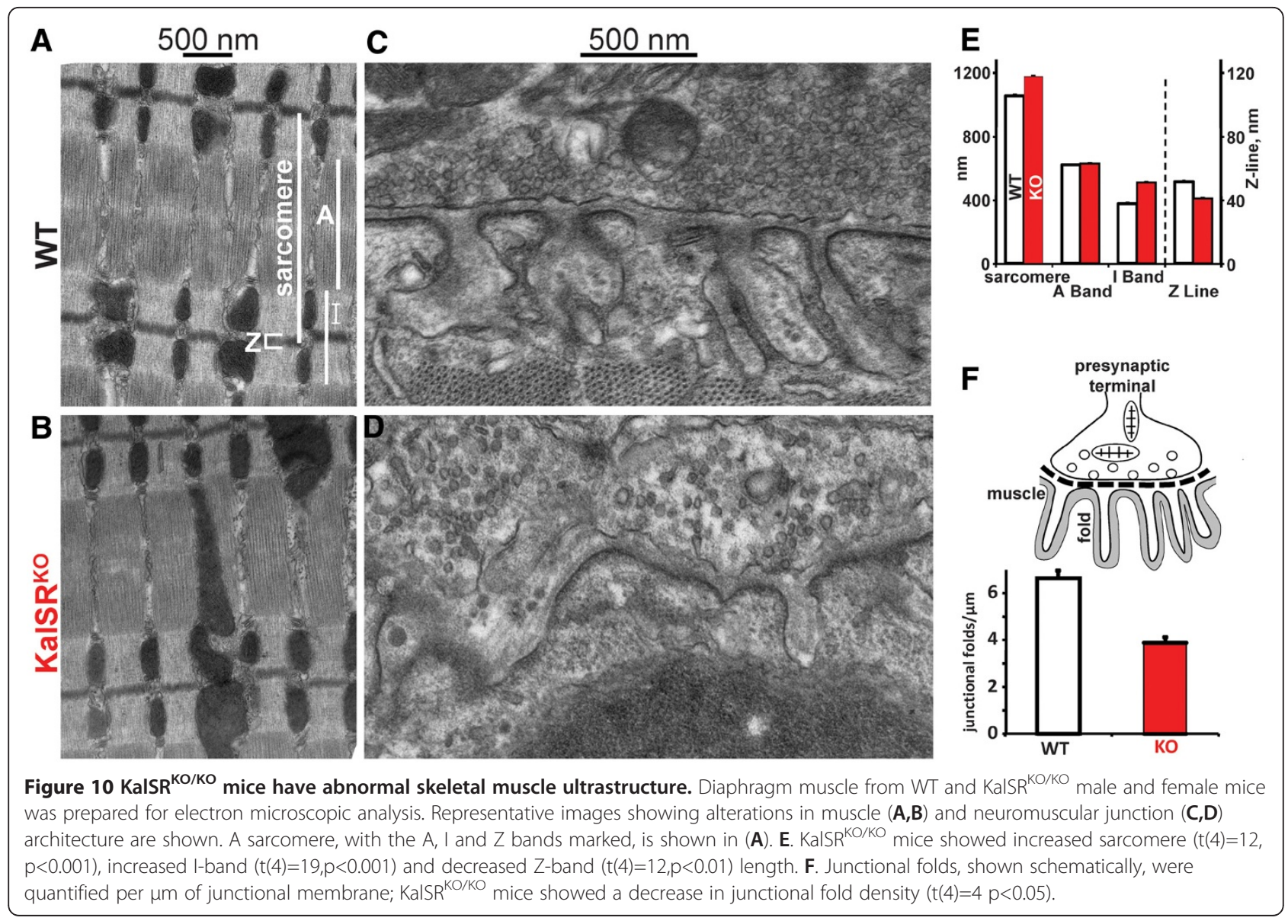




\section{Discussion and conclusion}

Genetic linkage studies and analyses of post-mortem tissue have associated human KALRN with a wide array of neuropsychiatric and cardiovascular diseases $[6,7,10,24,25,39,48]$. Detailed studies of the actions of Kalirin7, the major isoform in the adult nervous system, identified several pathways through which Kalirin7 can participate in spine formation and synaptic plasticity [13,17,18,49-51], but have not provided insight into the roles played by other Kalirin isoforms within or outside of the nervous system. Analysis of the C. elegans and D. melanogaster ortholog of Kalrn revealed essential roles for this gene both within and outside of the nervous system [52-55]; neither species has an isoform similar to Kalirin7.

\section{Functions unique to Kalirin9 and Kalirin12}

Kalirin 9 and Kalirin12 are expressed in skeletal muscle, pituitary, liver and aorta, but very little Kalirin7 is expressed outside of the nervous system. The second GEF domain of Kalrn, which is present in Kalirin9 and Kalirin12, but absent from Kalirin7, activates RhoA, not Rac1 or RhoG. The downstream effectors of Rac1 and RhoA are distinctly different $[1,56,57]$ and many of the disease-associated mutations identified in human KALRN map near the second GEF domain [6]. In the fly and worm orthologs of Kalrn, the Rac- and Rhospecific GEF domains play different but essential roles [52-54]. This strongly suggests unique roles for the Kalrn isoforms that contain the Rho-specific GEF2 domain. The GEF2 domain of UNC-73 plays a role in muscle contraction triggered through $G$ protein coupled receptors signaling through $\mathrm{G \alpha}_{\mathrm{q}}$ [22]. Structural analysis of a $G \alpha_{\mathrm{q}}$-p63RhoGEF-RhoA complex indicates that $\mathrm{G \alpha}_{\mathrm{q}}$ relieves the autoinhibitory effect of the PH domain; $\mathrm{G \alpha}_{\mathrm{q}}$ also activates the GEF2 domain of Kalrn [58]. Interactions unique to Kalirin12 have also been identified [59]; the binding of dynamin to the Ig/Fn domain is consistent with a role for Kalrn in endocytosis [60]. The fly and worm orthologs of Kalrn lack a kinase domain and offer no insight into its potential roles.

By comparing the phenotypes of the different Kalrn knockout mouse lines, we identified deficits caused by the loss of all of the Kalirin isoforms that were not observed in mice lacking only Kalirin7. Deficits observed in the $\mathrm{KalSR}{ }^{\mathrm{KO} / \mathrm{KO}}$ mice but not in the $\mathrm{Kal} 7^{\mathrm{KO} / \mathrm{KO}}$ mice presumably reflect the functions of Kalirin9 and -12 both within and outside of the nervous system. Deficits common to $\mathrm{KalSR}{ }^{\mathrm{KO} / \mathrm{KO}}$ and $\mathrm{Kal} 7^{\mathrm{KO} / \mathrm{KO}}$ mice reflect sites at which Kalirin7 is expressed and its unique localization to the PSD, where it can interact with PDZ domain containing proteins.

\section{Deficits unique to $\mathrm{KalSR}^{\mathrm{KO} / \mathrm{KO}}$ mice}

One of the most striking deficits unique to $\mathrm{KalSR}^{\mathrm{KO} / \mathrm{KO}}$ mice was their inability to perform in the rotarod and wire hang tests. That $\mathrm{KalSR}^{+/ K O}$ heterozygote mice also failed to perform normally in either test suggests that motor deficits are a sensitive indicator of compromised Kalrn function. Examination of the neuromuscular junction in $\mathrm{KalSR}^{\mathrm{KO} / \mathrm{KO}}$ mice revealed deficits in both the muscle and the presynaptic ending. A role for Kalrn in muscle is consistent with findings in C. elegans [22]. Splice variants of $U N C-73$ that resemble Kal Duet 9, a mammalian isoform generated from the Duet promoter, play essential roles in pharynx and vulval muscle [22]. In mammals, the Duet promoter also yields Kal Duet 12, which contains both a GEF domain and an active kinase domain [33].

The extensive signaling that occurs between skeletal muscle and the innervating motor neuron means that further experiments will be required to distinguish the roles of the different Kalrn isoforms in these two tissues. Kalirin9 and Kalirin12 are the most prevalent isoforms in the brain during embryonic development, and exogenous Kalirin9 or Kalirin12 in superior cervical ganglion neurons stimulated the initiation, growth and branching of axons [61]. Kalirin9 and Kalirin12 decline when Kalirin7 expression increases during the burst of synaptogenesis that occurs after birth [16]. Kalirin9, but not Kalirin7 or Kalirin12, binds p75 and regulates p75Nogo receptor-dependent RhoA activation in cerebellar granule neurons in culture, inhibiting myelin formation [62]. In Drosophila, dTrio interacts with Notch, affecting axon sprouting and guidance [63]; the GEF1 domain, but not the GEF2 domain, is essential for this interaction [23]. dTrio expressed in neurons is also a key component of the BMP retrograde signaling pathway used to coordinate pre- and post-synaptic development of the neuromuscular junction [55].

$\mathrm{KalSR}^{\mathrm{NesKO} / \mathrm{NesKO}}$ mice, which lack all isoforms of Kalrn in the nervous system, exhibited a deficit in rotarod behavior but were not impaired to the same extent as $\mathrm{KalSR}^{\mathrm{KO} / \mathrm{KO}}$ mice; $\mathrm{Kal} 7^{\mathrm{KO} / \mathrm{KO}}$ mice behaved like WT mice. Thus it is clear that isoforms of Kalrn expressed outside of the nervous system play an essential role in rotarod performance. Since Kalirin9 and Kalirin12 are expressed in skeletal muscle, the deficit may be a direct result of their absence from muscle cells. A better understanding of the role of Kalirin in skeletal muscle requires identifying the sites at which it is located. The clustering of receptors, ion channels and signaling proteins that occurs at the neuromuscular junction involves proteins similar to those involved in the formation of the PSD and skeletal muscle Kalirin could play a role in this process. The effect of Kalirin on the Z-line could be direct or indirect; many of the same 
proteins essential to spine formation and function participate in Z-line formation. The increase in sarcomere length observed in $\mathrm{KalSR}^{\mathrm{KO} / \mathrm{KO}}$ diaphragm muscle arose from an increase in the length of the I-band, which consists of actin filaments whose pointed ends extend between the myosin filaments. The barbed ends of the anti-parallel actin filaments from adjacent sarcomeres meet at the Z-line, which showed a decrease in width in $\mathrm{KalSR}^{\mathrm{KO} / \mathrm{KO}}$ mice. Z-line width is thought to correlate with the layers of $\alpha$-actinin that cross-link the antiparallel actin filaments [64]. $\alpha$-Actinin, which binds to NMDA receptors, is enriched at the PSD; when overexpressed in hippocampal neurons, $\alpha$-actinin increases the formation of long dendritic protrusions [65].

While loss of Kalirin expression in skeletal muscle may contribute to the inability of $\mathrm{KalSR}{ }^{\mathrm{KO} / \mathrm{KO}}$ mice to perform in the wire hang test, it is clear that expression of Kalirin7 in the nervous system also plays an important role in this behavioral response. $\mathrm{Kal} 7 \mathrm{KO} / \mathrm{KO}^{\mathrm{Ko}}$ mice remained suspended from the wire for a far longer time than WT mice, suggesting that central control of skeletal muscle has been altered. The KalSR ${ }^{\text {NesKO/NesKO }}$ mice exhibit a response intermediate to that of $\mathrm{KalSR}^{\mathrm{KO} / \mathrm{KO}}$ and $\mathrm{Kal} 7^{\mathrm{KO} / \mathrm{KO}}$ mice and similar to that of $\mathrm{KalSR}^{\mathrm{CKO} / \mathrm{CKO}}$ mice. The many pathways through which the CNS controls skeletal muscle contraction make it impossible to identify the sites at which Kalirin7 plays an essential role, but it is not uncommon for mouse mutants to show differential susceptibility to changes in performance in the wire hang and rotarod tests $[66,67]$.

The novel object recognition test revealed an intriguing difference between $\mathrm{KalSR}^{\mathrm{KO} / \mathrm{KO}}$ and $\mathrm{Kal} 7^{\mathrm{KO} / \mathrm{KO}}$ mice; while $\mathrm{KalSR}^{\mathrm{KO} / \mathrm{KO}}$ mice spent more total time exploring the objects than WT mice, $\mathrm{Kal} 7^{\mathrm{KO} / \mathrm{KO}}$ mice did not. This difference suggests that Kalirin9 and/or Kalirin12 contribute to this behavior. The age dependent hyperactive behavior reported in KalGEF1 $1^{\mathrm{KO} / \mathrm{KO}}$ mice [25] may be similar to the enhanced exploration of both familiar and novel objects seen with the $\mathrm{KalSR}^{\mathrm{KO} / \mathrm{KO}}$ mice, and may reflect the absence of Kalirin9 and/or Kalirin12. Due to the absence of Kalirin isoforms that include the GEF2 domain, the functioning of pathways that rely on GPCR signaling through $G \alpha_{\mathrm{q}}$ to RhoA may be impaired. Both cholinergic signaling through M1, M3 and M5 muscarinic receptors [68] and serotonergic signaling through $5 \mathrm{HT}_{2 \mathrm{~A}}$ and $5 \mathrm{HT}_{2 \mathrm{C}}$ receptors involve $\mathrm{G \alpha}_{\mathrm{q}}$ $[69,70]$.

A role for Kalirin in secretory granule release was expected from previous studies using pituitary cells in culture [30], from the fact that Kalirin was first identified through its interaction with a secretory granule membrane protein and from the altered neurotransmitter release observed in worms and flies [22,52-55]. The increased basal secretion of PRL and GH observed in $\mathrm{KalSR}^{\mathrm{KO} / \mathrm{KO}}$ pituitary cells in culture may underlie the growth deficits in the animal, since elevated GH without the normal periodicity in its secretion contributes to stunted growth in experimental animals and across the human population [38,71,72]. Altered basal secretion of peptides could be expected to contribute to other deficits observed in $\mathrm{KalSR}^{\mathrm{KO} / \mathrm{KO}}$ mice, especially at the neuromuscular junction.

\section{Deficits common to KalSR ${ }^{\mathrm{KO} / \mathrm{KO}}$ and $\mathrm{Kal}^{\mathrm{KO} / \mathrm{KO}}$ mice}

A similar decrease in baseline anxiety-like behavior was seen in both $\mathrm{KalSR}{ }^{\mathrm{KO} / \mathrm{KO}}$ and $\mathrm{Kal} 7^{\mathrm{KO} / \mathrm{KO}}$ mice. $\mathrm{KalSR}^{\mathrm{KO} / \mathrm{KO}}$ mice and $\mathrm{Kal} 7^{\mathrm{KO} / \mathrm{KO}}$ mice also exhibited comparably impaired passive avoidance behavior. Since $\mathrm{Kal} 7^{\mathrm{KO} / \mathrm{KO}}$ mice produce slightly increased amounts of Kalirin9 and Kalirin12 compared to WT mice [13], we think it likely that a lack of Kalirin7 causes the changes observed in the affected pathways. It is clear that Kalirin7 plays an essential role in the formation and function of excitatory synapses on dendritic spines. Both NMDA receptor dependent LTP and LTD are deficient in $\mathrm{Kal} 7^{\mathrm{KO} / \mathrm{KO}}$ mice [73]. In the absence of Kalirin7, chronic cocaine treatment is unable to increase the size or the number of spines on the dendrites of medium spiny neurons in the nucleus accumbens [24]. In hippocampal cultures, a decrease in Kalirin7 expression both reduced the density of excitatory synapses and the ability of estadiol to increase synapse formation [19].

Expression of Kalirin in the amygdala, one of the regions that plays a critical role in anxiety-like behavior and passive avoidance, is not notably different from expression levels elsewhere in the brain, but region or cell-type specific differences in the expression of key interactors may determine which pathways are most sensitive to a decrease in Kalirin7 levels. Many of proteins identified in a screen for Kalirin7 PDZ binding motif interactors are known to be involved in the clustering of NMDA and AMPA receptors (PSD-95, SAP102, SAP97, Chapsyn-110, PICK-1) [15,49]. Other interactors link Kalirin7 to filamentous actin (ZO-1, ZO-2, neurabin, spinophilin, AF-6/afadin), a key determinant of spine shape and thus of spine function. Of special interest, given the role of serotoninergic transmission in anxiety and fear, is MUPP1, which binds to both Kalirin7 and to the $5 \mathrm{HT}_{2 \mathrm{~A}}$ and $5 \mathrm{HT}_{2 \mathrm{C}}$ receptors $[15,74]$.

Kalirin7, Kalirin9 and Kalirin12 share the ability to interact with a wide variety of proteins including peptidylglycine $\alpha$-amidating monoxygenase (PAM) [75], DISC-1 [9], TrkB [76], inducible NOS [77], NR2B [29] and phosphoinositides [60] through their common Sec14, spectrin repeat and GEF1 domains. 


\section{Manipulating Kalrn to study psychiatric/ neurological disorders}

KALRN has been linked to schizophrenia and adult ADHD, and mouse models for these diseases would be of great use. Patients suffering from a variety of neuropsychiatric disorders including schizophrenia, obsessive compulsive disorder and Huntington's disease often exhibit deficits in prepulse inhibition [45,78,79]. The linkage of KALRN to schizophrenia and the interaction of Kalirin with DISC-1 made prepulse inhibition, which can be modeled in rodents [45], of particular interest. However, in a test of prepulse inhibition of acoustic startle, KalSR ${ }^{\mathrm{KO} / \mathrm{KO}}$ mice showed no sensorimotor deficits; $\mathrm{KalSR}^{\mathrm{KO} / \mathrm{KO}}$ mice evinced a decreased startle response in the pulse alone trials, demonstrating deficits in their baseline startle response. While $\mathrm{KalGEF1}{ }^{\mathrm{KO} / \mathrm{KO}}$ mice showed reduced prepulse inhibition of acoustic startle relative to WT mice [25], neither the WT nor the Kal$\mathrm{GEF} 1^{\mathrm{KO} / \mathrm{KO}}$ mice showed the expected intensity dependence of prepulse induced inhibition [25]. The fact that both WT and KalSR ${ }^{\mathrm{KO} / \mathrm{KO}}$ mice showed a graded increase in inhibition of acoustic startle with increasing prepulse intensity supports the conclusion that ablation of Kalrn did not result in a hearing or response deficit. Several studies have noted significant co-morbidity of neuromuscular deficits and schizophrenia [80-82], which might be associated with deficits in KALRN.

\section{Competing interests}

The authors declare that they have no competing interests.

\section{Authors' contributions}

Designed research: PM,BAE,REM, Performed research: PM,MY,LHC,XM,BAE, REM, Analyzed data: PM,LHC,JG,BAE,REM, Wrote the paper: PM,BAE,REM. All authors read and approved the final manuscript.

\section{Acknowledgements}

We thank Darlene D'Amato, Yanping Wang and Taylor Larese for tireless lab assistance and Dr. Qian Wu for her help interpreting electron micrographs of skeletal muscle. This work was supported by NIH grant DK-32948.

\section{Author details \\ ${ }^{1}$ Department of Neuroscience, University of Connecticut Health Science Center, Farmington, CT 06030-3401, USA. ${ }^{2}$ Molecular Microbial \& Structural Biology, University of Connecticut Health Science Center, Farmington, CT 06030-3401, USA. ${ }^{3}$ Psychiatry, University of Connecticut Health Science Center, Farmington, CT 06030-3401, USA. ${ }^{4}$ Connecticut Institute Clinical Translational Science, University of Connecticut Health Science Center, Farmington, CT 06030-3401, USA.}

Received: 21 November 2011 Accepted: 22 October 2012 Published: 1 November 2012

\section{References}

1. Kiraly DD, Eipper-Mains JE, Mains RE, Eipper BA: Synaptic Plasticity, a Symphony in GEF. ACS Chem Neurosci 2010, 1:348-365.

2. Krug T, Manso H, Gouveia L, Sobral J, Xavier JM, Oliveira SA: Kalirin: a novel genetic risk factor for ischemic stroke. Hum Genet 2010, 127:513-523.

3. Wang L, Hauser ER, Shah SH, Pericak-Vance MA, Goldschmidt-Clermont PJ, Vance JM: Peakwide mapping on chromosome $3 q 13$ identifies the Kalirin gene as a novel candidate gene for coronary artery disease. Am J Hum Genet 2007, 80:650-663.
4. Beresewicz M, Kowalczyk JE, Jablocka B: Kalirin-7, a protein enriched in postsynaptic density, is involved in ischemic signal transduction. Neurochem Res 2008, 33:1789-1794.

5. Fanaroff AC, Wu JH, Zhang L, Peppel K, Brian L, Eipper BA, Mains RE, Freedman NJ: The Dual Rho-GEF Kalirin Promotes Atherosclerosis by Augmenting Smooth Muscle Cell Rac1 Signaling, Migration, and Proliferation. Circulation 2010, 122:A18017.

6. Kushima I, Nakamura Y, Aleksic B, Ikeda M, Ito $Y$, Shiino T, Okochi T, Fukuo $Y$, Ujike H, Suzuki M, Inada T, Hashimoto R, Takeda M, Kaibuchi K, Iwata N, Ozaki N: Resequencing and Association Analysis of the KALRN and EPHB1 Genes And Their Contribution to Schizophrenia Susceptibility. Schizophr Bull 2012, 38:552-560.

7. Hill JJ, Hashimoto T, Lewis DA: Molecular mechanisms contributing to dendritic spine alterations in the prefrontal cortex of subjects with schizophrenia. Mol Psychiatry 2006, 11:557-566.

8. Bradshaw NJ, Porteous DJ: DISC1-binding proteins in neural development, signalling and schizophrenia. Neuropharmacology 2012, 62:1230-1241

9. Hayashi-Takagi A, Takaki M, Graziane N, Seshadri S, Murdoch H, Dunlop AJ, Makino Y, Seshadri AJ, Ishizuka K, Srivastava DP, Xie Z, Baraban JM, Houslay MD, Tomoda T, Brandon NJ, Kamiya A, Yan Z, Penzes P, Sawa A: Disrupted-in-Schizophrenia 1 (DISC1) regulates spines of the glutamate synapse via Rac1. Nat Neurosci 2010, 13:327-332.

10. Lesch KP, Timmesfeld N, Renner TJ, Halperin R, Roser C, Nguyen TT, Craig DW, Romanos J, Heine M, Meyer J, Freitag C, Warnke A, Romanos M, Schafer H, Walitza S, Reif A, Stephan DA, Jacob C: Molecular genetics of adult ADHD: converging evidence from genome-wide association and extended pedigree linkage studies. J Neural Transm 2008, 115:1573-1585.

11. Johnson RC, Penzes P, Eipper BA, Mains RE: Isoforms of kalirin, a neuronal Dbl family member, generated through use of different $5^{\prime}$ - and $3^{\prime}$-ends along with an internal translational initiation site. J Biol Chem 2000, 275:19324-19333.

12. McPherson CE, Eipper BA, Mains RE: Kalirin expression is regulated by multiple promoters. J Mol Neurosci 2004, 22:51-62.

13. Ma XM, Kiraly DD, Gaier ED, Wang Y, Kim EJ, Levine ES, Eipper BA, Mains RE: Kalirin-7 is required for synaptic structure and function. J Neurosci 2008, 28:12368-12382.

14. Rabiner CA, Mains RE, Eipper BA: Kalirin: a dual Rho guanine nucleotide exchange factor that is so much more than the sum of its many parts. Neuroscientist 2005, 11:148-160.

15. Penzes $P$, Johnson RC, Sattler R, Zhang X, Huganir RL, Kambampati V, Mains RE, Eipper BA: The neuronal Rho-GEF Kalirin-7 interacts with PDZ domain-containing proteins and regulates dendritic morphogenesis. Neuron 2001, 29:229-242.

16. Ma XM, Huang J, Wang Y, Eipper BA, Mains RE: Kalirin, a multifunctional Rho guanine nucleotide exchange factor, is necessary for maintenance of hippocampal pyramidal neuron dendrites and dendritic spines. J Neurosci 2003, 23:10593-10603.

17. Xie Z, Srivastava DP, Photowala H, Kai L, Cahill ME, Woolfrey KM, Shum CY, Surmeier DJ, Penzes P: Kalirin-7 controls activity-dependent structural and functional plasticity of dendritic spines. Neuron 2007, 56:640-656.

18. Ma XM, Wang Y, Ferraro F, Mains RE, Eipper BA: Kalirin-7 is an essential component of both shaft and spine excitatory synapses in hippocampal interneurons. J Neurosci 2008, 28:711-724.

19. Ma XM, Huang JP, Kim EJ, Zhu Q, Kuchel GA, Mains RE, Eipper BA: Kalirin-7, an important component of excitatory synapses, is regulated by estradiol in hippocampal neurons. Hippocampus 2011, 21:661-677.

20. Hansel DE, Quinones ME, Ronnett GV, Eipper BA: Kalirin, a GDP/GTP exchange factor of the Dbl family, is localized to nerve, muscle, and endocrine tissue during embryonic rat development. J Histochem Cytochem 2001, 49:833-844.

21. Muth E, Driscoll WJ, Smalstig A, Goping G, Mueller GP: Proteomic analysis of rat atrial secretory granules: a platform for testable hypotheses. Biochim Biophys Acta 2004, 1699:263-275.

22. Steven R, Zhang L, Culotti J, Pawson T: The UNC-73/Trio RhoGEF-2 domain is required in separate isoforms for the regulation of pharynx pumping and normal neurotransmission in C. elegans. Genes Dev 2005, 19:2016-2029.

23. Song JK, Giniger E: Noncanonical Notch function in motor axon guidance is mediated by Rac GTPase and the GEF1 domain of Trio. Dev Dyn 2011, 240:324-332. 
24. Kiraly DD, Ma XM, Mazzone CM, Xin X, Mains RE, Eipper BA: Behavioral and morphological responses to cocaine require kalirin7. Biol Psychiatry 2010, 68:249-255

25. Cahill ME, Xie Z, Day M, Photowala H, Barbolina MV, Miller CA, Weiss C, Radulovic J, Sweatt JD, Disterhoft JF, Surmeier DJ, Penzes P: Kalirin regulates cortical spine morphogenesis and disease-related behavioral phenotypes. Proc Natl Acad Sci USA 2009, 106:13058-13063.

26. Bousquet-Moore D, Ma XM, Nillni EA, Czyzyk TA, Pintar JE, Eipper BA, Mains RE: Reversal of physiological deficits caused by diminished levels of peptidylglycine alpha-amidating monooxygenase by dietary copper. Endocrinology 2009, 150:1739-1747.

27. Conti LH, Sutherland JE, Muhlhauser CM: Interaction between the effects of corticotropin-releasing factor and prepulse parameters on prepulse inhibition in two inbred rat strains and the F1 generation of a cross between them. Behav Brain Res 2009, 200:165-172

28. Mains RE, Kiraly DD, Eipper-Mains JE, Ma XM, Eipper BA: Kalrn promoter usage and isoform expression respond to chronic cocaine exposure. BMC Neurosci 2011, 12:20.

29. Kiraly DD, Stone KL, Colangelo CM, Abbott T, Wang Y, Mains RE, Eipper BA: Identification of Kalirin-7 as a Potential Post-Synaptic Density Signaling Hub. J Proteome Res 2011, 10:2828-2841.

30. Ferraro F, Ma XM, Sobota JA, Eipper BA, Mains RE: Kalirin/Trio Rho guanine nucleotide exchange factors regulate a novel step in secretory granule maturation. Mol Biol Cell 2007, 18:4813-4825.

31. Dickerson IM, Mains RE: Cell-type specific posttranslational processing of peptides by different pituitary cell lines. Endocrinology 1990, 127:133-140.

32. Shi $L$, Butt $B$, Ip FC, Dai $Y$, Jiang $L$, Yung WH, Greenberg ME, Fu AK, Ip NY Ephexin1 is required for structural maturation and neurotransmission at the neuromuscular junction. Neuron 2010, 65:204-216.

33. Kawai T, Sanjo H, Akira S: Duet is a novel serine/threonine kinase with Dbl-Homology (DH) and Pleckstrin-Homology (PH) domains. Gene 1999, 227:249-255.

34. Hwang J, Maquat LE: Nonsense-mediated mRNA decay (NMD) in animal embryogenesis: to die or not to die, that is the question. Curr Opin Genet Dev 2011, 21:422-430.

35. Bhuvanagiri M, Schlitter AM, Hentze MW, Kulozik AE: NMD: RNA biology meets human genetic medicine. Biochem J 2010, 430:365-377.

36. Buratti E, Baralle FE: TDP-43: new aspects of autoregulation mechanisms in RNA binding proteins and their connection with human disease. FEBS J 2011, 278:3530-3538.

37. Grady JJ: Analysis of change. Methods Mol Biol 2007, 404:261-271.

38. del Pozo E, Zapf J, Mackenzie AR, Janner M, Perrelet R, Lippuner K, Mullis P: Experimental arthritis: effect on growth parameters and total skeletal calcium. Growth Horm IGF Res 2009, 19:442-446.

39. Wang L, Hauser ER, Shah SH, Pericak-Vance MA, Haynes C, Crosslin D, Harris M, Nelson S, Hale AB, Granger CB, Haines JL, Jones CJ, Crossman D, Seo D, Gregory SG, Kraus WE, Goldschmidt-Clermont PJ, Vance JM: Peakwide mapping on chromosome $3 q 13$ identifies the kalirin gene as a novel candidate gene for coronary artery disease. Am J Hum Genet 2007 80:650-663

40. Goel N, Bale TL: Sex differences in the serotonergic influence on the hypothalamic-pituitary-adrenal stress axis. Endocrinology 2010, 151:1784-1794.

41. Youn H, Ji I, Ji HP, Markesbery WR, Ji TH: Under-expression of Kalirin-7 Increases iNOS activity in cultured cells and correlates to elevated iNOS activity in Alzheimer's disease hippocampus. J Alzheimers Dis 2007, 12:271-281.

42. Zhuang X, Oosting RS, Jones SR, Gainetdinov RR, Miller GW, Caron MG, Hen $R$ : Hyperactivity and impaired response habituation in hyperdopaminergic mice. Proc Natl Acad Sci USA 2001, 98:1982-1987

43. Geyer MA, Krebs-Thomson K, Braff DL, Swerdlow NR: Pharmacological studies of prepulse inhibition models of sensorimotor gating deficits in schizophrenia: a decade in review. Psychopharmacology (Berl) 2001, 156:117-154.

44. Narayan S, Tang B, Head SR, Gilmartin TJ, Sutcliffe JG, Dean B, Thomas EA: Molecular profiles of schizophrenia in the CNS at different stages of illness. Brain Res 2008, 1239:235-248.

45. Braff DL, Geyer MA, Swerdlow NR: Human studies of prepulse inhibition of startle: normal subjects, patient groups, and pharmacological studies. Psychopharmacology (Berl) 2001, 156:234-258.
46. Tronche F, Kellendonk C, Kretz O, Gass P, Anlag K, Orban PC, Bock R, Klein R, Schutz G: Disruption of the glucocorticoid receptor gene in the nervous system results in reduced anxiety. Nat Genet 1999, 23:99-103.

47. De Harven E: COERS C: Electron microscope study of the human neuromuscular junction. J Biophys Biochem Cytol 1959, 6:7-10.

48. Beresewicz M, Kowalczyk JE, Zablocka B: Kalirin-7, a protein enriched in postsynaptic density, is involved in ischemic signal transduction. Neurochem Res 2008, 33:1789-1794.

49. Xie Z, Photowala H, Cahill ME, Srivastava DP, Woolfrey KM, Shum CY, Huganir RL, Penzes P: Coordination of synaptic adhesion with dendritic spine remodeling by AF-6 and kalirin-7. J Neurosci 2008, 28:6079-6091.

50. Penzes P, Cahill ME, Jones KA, Vanleeuwen JE, Woolfrey KM: Dendritic spine pathology in neuropsychiatric disorders. Nat Neurosci 2011, 14:285-293.

51. Mandela P, Ma XM: Kalirin, a Key Player in Synapse Formation, Is Implicated in Human Diseases. Neural Plast 2012, doi:10.1155/2012/728161.

52. Chan JP, Hu Z, Sieburth D: Recruitment of sphingosine kinase to presynaptic terminals by a conserved muscarinic signaling pathway promotes neurotransmitter release. Genes \& Devel 2012, 26:1070-1085.

53. Williams SL, Lutz S, Charlie NK, Vettel C, Tesmer JJG, Jorgensen EM, Wieland T, Miller KG: Trio's Rho-specific GEF domain is the missing Gq effector in C. elegans. Genes \& Devel 2007, 21:2731-2746.

54. McMullan R, Anderson A, Nurrish S: Behavioral and Immune Responses to Infection Require Gaq-RhoA Signaling in C. elegans. PLoS Pathog 2012, 8:e1002530.

55. Ball RW, Warren-Paquin M, Tsurudome K, Liao EH, Elazzouzi F, Cavanagh C, An BS, Wang TT, White JH, Haghighi AP: Retrograde BMP signaling controls synaptic growth at the NMJ by regulating trio expression in motor neurons. Neuron 2010, 66:536-549.

56. Tolias KF, Duman JG, Um K: Control of synapse development and plasticity by Rho GTPase regulatory proteins. Prog Neurobiol 2011, 94:133-148.

57. Rossman KL, Der CJ, Sondek J: GEF means go: turning on Rho GTPases with guanine nucleotide-exchange factors. Nature Rev Mol Cell Biol 2005, 6:167-180.

58. Lutz S, Shankaranarayanan A, Coco C, Ridilla M, Wieland T, Tesmer JJG: Structure of G-alpha-q-p63RhoGEF-RhoA Complex Reveals a Pathway for the Activation of RhoA by GPCRs. Science 2007, 318:1923-1927.

59. Xin X, Rabiner CA, Mains RE, Eipper BA: Kalirin12 interacts with dynamin. BMC Neurosci 2009, 10:61.

60. Schiller MR, Ferraro F, Wang Y, Ma XM, McPherson CE, Sobota JA, Schiller NI, Mains RE, Eipper BA: Autonomous functions for the Sec14p/spectrinrepeat region of Kalirin. Exp Cell Res 2008, 314:2674-2691.

61. May V, Schiller MR, Eipper BA, Mains RE: Kalirin Dbl-homology guanine nucleotide exchange factor 1 domain initiates new axon outgrowths via Rho-G mediated mechanisms. J Neuroscience 2002, 22:6980-6990.

62. Harrington AW, Li QM, Tep C, Park JB, He Z, Yoon SO: The role of Kalirin9 in p75/nogo receptor-mediated RhoA activation in cerebellar granule neurons. JBC 2008, 283:24690-24697.

63. Le GM, De MC, Giniger E: Molecular separation of two signaling pathways for the receptor, Notch. Dev Biol 2008, 313:556-567.

64. Luther PK: The vertebrate muscle Z-disc: sarcomere anchor for structure and signalling. J Muscle Res Cell Motil 2009, 30:171-185.

65. Nakagawa T, Engler JA, Sheng M: The dynamic turnover and functional roles of alpha-actinin in dendritic spines. Neuropharmacology 2004, 47:734-745

66. Brooks S, Higgs G, Jones L, Dunnett SB: Longitudinal analysis of the behavioural phenotype in $\mathrm{Hdh}((\mathrm{CAG}) 150)$ Huntington's disease knock-in mice. Brain Res Bull 2010, PMID:20457230.

67. Foley JW, Bercury SD, Finn P, Cheng SH, Scheule RK, Ziegler RJ: Evaluation of systemic follistatin as an adjuvant to stimulate muscle repair and improve motor function in Pompe mice. Mol Ther 2010, 18:1584-1591.

68. Brown DA: Muscarininc acetylcholine receptors (mAChRs) in the nervous system: some functions and mechanisms. J Mol Neurosci 2010, 41:340-346.

69. Schmauss C, Zimnisky R, Mehta M, Shapiro LP: The roles of phospholipase $C$ activation and alternative ADAR1 and ADAR2 pre-mRNA splicing in modulating serotonin 2C-receptor editing in vivo. RNA 2010, 16:1779-1785.

70. Nunez-de-Souza V, Nunez-de-Souza RL, Rodgers RJ, Canto-de-Souza A: $5-\mathrm{HT} 2$ receptor activation in the midbrain periaqueductal grey (PAG) reduces anxiety-like behavior in mice. Behav Brain Res 2008, 187:72-79. 
71. Challa A, Krieg RJ Jr, Thabet MA, Veldhuis JD, Chan JC: Metabolic acidosis inhibits growth hormone secretion in rats: mechanism of growth retardation. Am J Physiol 1993, 265:E547-E553.

72. Rochiccioli P, Messina A, Tauber MT, Enjaume C: Correlation of the parameters of 24-hour growth hormone secretion with growth velocity in 93 children of varying height. Horm Res 1989, 31:115-118.

73. Lemtiri-Chlieh F, Zhao L, Kiraly DD, Eipper BA, Mains RE, Levine ES: Kalirin-7 is necessary for normal NMDA receptor-dependent synaptic plasticity. BMC Neurosci 2012, 12:126.

74. Jones KA, Srivastava DP, Allen JA, Strachan RT, Roth BL, Penzes P: Rapid modulation of spine morphology by the $5-\mathrm{HT} 2 \mathrm{~A}$ serotonin receptor through kalirin-7 signaling. PNAS 2009, 106:19575-19580.

75. Alam MR, Caldwell BD, Johnson RC, Darlington DN, Mains RE, Eipper BA: Novel proteins that interact with the $\mathrm{COOH}$-terminal cytosolic routing determinants of an integral membrane peptide-processing enzyme. J Biol Chem 1996, 271:28636-28640.

76. Chakrabarti K, Lin R, Schiller NI, Wang Y, Koubi D, Fan YX, Rudkin BB, Johnson GR, Schiller MR: Critical role for Kalirin in nerve growth factor signaling through TrkA. Mol Cell Biol 2005, 25:5106-5118.

77. Ratovitski EA, Alam MR, Quick RA, McMillan A, Bao C, Kozlovsky C, Hand TA Johnson RC, Mains RE, Eipper BA, Lowenstein CJ: Kalirin inhibition of inducible nitric-oxide synthase. J Biol Chem 1999, 274:993-999.

78. Parwani A, Duncan EJ, Bartlett E, Madonick SH, Efferen TR, Rajan R, Sanfilipo M, Chappell PB, Chakravorty S, Gonzenbach S, Ko GN, Rotrosen JP: Impaired prepulse inhibition of acoustic startle in schizophrenia. Biol Psychiatry 2000, 47:662-669.

79. Schall U, Schon A, Zerbin D, Eggers C, Oades RD: Event-related potentials during an auditory discrimination with prepulse inhibition in patients with schizophrenia, obsessive-compulsive disorder and healthy subjects. Int J Neurosci 1996, 84:15-33.

80. Manschreck TC, Ames D: Neurologic features and psychopathology in schizophrenic disorders. Biol Psychiatry 1984, 19:703-719.

81. Manschreck TC, Maher ER, Candela SF: Earlier age of first diagnosis in schizophrenia is related to impaired motor control. Schizophr Bull 2004, 30:351-360.

82. Skirbekk B, Hansen BH, Oerbeck B, Wentzel-Larsen T, Kristensen H: Motor impairment in children with anxiety disorders. Psychiatry Res 2012, 198:135-139.

doi:10.1186/1471-2202-13-136

Cite this article as: Mandela et al:: Kalrn plays key roles within and outside of the nervous system. BMC Neuroscience 2012 13:136.

\section{Submit your next manuscript to BioMed Central and take full advantage of:}

- Convenient online submission

- Thorough peer review

- No space constraints or color figure charges

- Immediate publication on acceptance

- Inclusion in PubMed, CAS, Scopus and Google Scholar

- Research which is freely available for redistribution

Submit your manuscript at www.biomedcentral.com/submit 